\title{
Magnitude and maintenance of the phytoplankton bloom at South Georgia: a naturally iron-replete environment
}

\author{
R. E. Korb*, M. J. Whitehouse, A. Atkinson, S. E. Thorpe \\ British Antarctic Survey, High Cross, Madingley Road, Cambridge, CB3 0ET, UK
}

\begin{abstract}
We investigated phytoplankton blooms around the island of South Georgia, in the South Atlantic sector of the Southern Ocean, during 3 austral summer cruises. Blooms developed largely to the northwest, downstream of the island, in the Georgia Basin. Drifter buoys approached the island from the southwest and diverged in the region of ca. $55^{\circ} \mathrm{S}, 40^{\circ} \mathrm{W}$, to pass either to the west or east of the island and into the main bloom area of the Georgia Basin. The divergence zone indicated a likely site of upwelling of nutrient-rich deepwater, whilst the eastward flowing drifters indicated nutrient enrichment through shelf sediment interactions along the southern and eastern shelf. South Georgia's summer phytoplankton blooms were characteristic of those found in Fe-replete environments. Water column standing stocks of chl $a$ and primary production rates were 3 times higher at stations situated within the main bloom (in-stations) compared to those outside of the bloom (out-stations). $\mathrm{NO}_{3}: \mathrm{PO}_{4}$ depletion ratios were significantly higher and $\mathrm{Si}(\mathrm{OH})_{4}: \mathrm{NO}_{3}$ depletion ratios lower at in-stations compared to out-stations and were in the range expected under Fe-replete conditions. High photochemical quantum efficiency $\left(F_{\mathrm{v}} / F_{\mathrm{m}}\right)$ and low functional absorption cross-section $\left(\sigma_{\mathrm{PSII}}\right)$ values, measured during our January 2005 cruise, further supported the view that in-stations were Fe-rich. However, on all cruises, both in- and out-stations were strongly dominated by the largest chl a sizefraction (microphytoplankton), and diatoms accounted for $>63 \%$ of the total cell count. Reduced availability of $\mathrm{Fe}$ at out-stations may have prevented very large species of diatoms from blooming there, but did allow a modest accumulation of smaller diatoms. Simultaneous limitation of Fe with silicic acid or temperature may also account for the species composition and reduced productivity observed at some out-stations. Conversely, a steady supply of Fe and macronutrients, together with shallow mixed layers and slightly elevated temperatures, could account for the blooms of giant diatoms observed at in-stations.
\end{abstract}

KEY WORDS: South Georgia $\cdot$ Phytoplankton blooms · Drifter tracks $\cdot$ Iron $\cdot$ Silicic acid $\cdot$ Diatoms

Resale or republication not permitted without written consent of the publisher

\section{INTRODUCTION}

Despite much of the Southern Ocean being characterised by High-Nutrient Low-Chlorophyll (HNLC) conditions, there are regions where persistent blooms occur. Within the open ocean, elevated chl a levels and high rates of primary production are often associated with topographic features such as oceanic islands or seamounts (Comiso et al. 1993, Moore \& Abbott 2000, Holm-Hansen et al. 2005, Tyrrell et al. 2005, Blain et al. 2007, Pollard et al. 2007, Sokolov \& Rintoul
2007). A lack of Fe in surface waters is often a key factor creating the HNLC conditions in the Southern Ocean (e.g. de Baar et al. 2005, Boyd et al. 2007). In contrast, blooms indicate waters replete in $\mathrm{Fe}$ and bathymetric features can promote Fe-enrichment of surface waters from upwelling processes or from shelf sediment (e.g. Holm-Hansen et al. 2005). Recent studies have confirmed that $\mathrm{Fe}$ from the subantarctic islands of Crozet and Kerguelen fertilized the blooms found there (Blain et al. 2007, Planquette et al. 2007, Pollard et al. 2007). Another area of possible Fe- 
enrichment is in the wake of the island of South Georgia, in the northern Scotia Sea (Fig. 1a), where large and intense phytoplankton blooms regularly occur and may last for 4 to 6 mo (Atkinson et al. 2001, Korb \& Whitehouse 2004, Korb et al. 2004, Whitehouse et al. 2008).

South Georgia's blooms are typically found extending from the island's southwestern shelf downstream into the generally cyclonic circulation of the Georgia Basin (Fig. 1b) and can cover an area of ca. $53000 \mathrm{~km}^{2}$. Assuming an average integrated chl a concentration of $104 \mathrm{mg} \mathrm{m}^{-2}$ (using values from the present study), a carbon:chlorophyll ratio of between 75:1 and 150:1 (Larsson 2004), the standing stock of carbon biomass of the South Georgia bloom in the euphotic zone, which is potentially available to grazers and/or for export to the deep ocean during the austral summer, is in the order of 0.41 to $0.83 \mathrm{Tg}$. Not surprisingly, South Georgia's blooms are associated with the strongest predicted carbon sink in the Southern Ocean (Schlitzer 2002), and the enhanced primary productivity supports a rich and commercially valuable food web (Atkinson et al. 2001). The complex oceanic circulation around South Georgia contributes to the high productivity found in the Georgia Basin. There is evidence of upwelling of macronutrient-rich waters into the euphotic zone at the island's southwestern (upstream) shelf edge (Whitehouse et al. 2008). In addition, to the north of the island, circulation over bathymetric features such as the Northwest Georgia Rise and the interaction of the Southern Antarctic Circumpolar Current Front (SACCF) with bathymetry may also promote upwelling (Ward et al. 2002, Meredith et al. 2003a). The magnitude and longevity of South Georgia's blooms indicate an environment replete in Fe which is likely re-supplied by the topography of the region throughout the growing season. Waters leaving the Georgia Basin flow eastwards along the Polar Front (PF) and chl a can remain elevated along the PF for hundreds of kilometers downstream of the island (de Baar et al. 1995, Korb et al. 2004). South Georgia may be partly responsible for the elevated Fe levels which were found some 20 to $30^{\circ}$ eastwards of the island (de Baar et al. 1995).

In the present study, we examined the mechanisms that may be responsible for promoting and sustaining the huge blooms which are annually observed at South Georgia. We examined the macronutrient phytoplankton community composition, biomass and primary production distributions from 3 cruises to the South Georgia region. We compared data collected in highly productive areas to data collected from less productive regions close to the island. In addition, we used Lagrangian near-surface drifter data and remotely sensed sea surface colour data to examine water flow and patterns of chl a biomass around the island. The present study demonstrated that South Georgia's summer phytoplankton communities are characteristic of an Fe-replete environment and show how waters in the Georgia Basin could become enriched in Fe and macronutrients.

\section{MATERIALS AND METHODS}

Study area. The shipboard data in the present study were collected from the British Antarctic Survey's (BAS) RV 'RRS James Clark Ross' during 3 cruises: JR70 between 6 January and 3 February 2002, JR82 between 9 January and 16 February 2003 and JR116 between 26 December 2004 and 14 January 2005. Hereafter, we refer to these cruises by the year in which the cruise ended, e.g. cruise JR70 is termed the 2002 cruise. Cruises consisted of underway measurements and station-based sampling at various locations in the Scotia Sea, but here we consider only the stations in the vicinity of South Georgia (Fig. 1c). A $10 \mathrm{yr}$ SeaWiFS summer composite (Fig. 1b) was used to define the main geographical extent of South Georgia's blooms. Comiso et al. (1993) defined Southern Ocean blooms as having chl a concentrations $>1 \mathrm{mg} \mathrm{m}^{-3}$. However, in the Scotia Sea, SeaWiFS underestimates chl a concentrations when in situ values are high (e.g. $>1 \mathrm{mg} \mathrm{m}^{-3}$; Holm-Hansen et al. 2004a, Korb et al. 2004). Therefore, in the present study, we have chosen a slightly more conservative value and to qualify as bloom conditions, the SeaWiFS chl a concentration of the composite image had to be $\geq 0.75 \mathrm{mg} \mathrm{m}^{-3}$. The area covered by this 10 yr composite bloom was termed the SG-bloom and, for the purposes of the present study, stations were divided into 2 groups: those located within the area of the main SG-bloom (referred to as in-stations) and those located outside of the main composite bloom (out-stations). Chl a was patchy to the south of the island and so the southern stations of our 2005 cruise were considered in-stations if they were located on the southern shelf of the island.

Water sampling and physical measurements. Vertical profiles of temperature, salinity and depth were measured using a SeaBird 911+ CTD. A SeaBird 12position carousel water sampler with 101 Niskin bottles was used to collect discrete water samples from the upcast of the CTD to measure chl $a$, primary production, nutrients and cell counts. An Aqua-Tracka Mk III fluorometer (Chelsea Instruments) and a PAR sensor (Biospherical Instruments) were mounted on the CTD frame. All of the sensor data from the downcast of the CTD were averaged onto 2 dbar pressure levels for analysis. Fluorescence profiles from the Aqua Tracka were calibrated against extracted chl a 

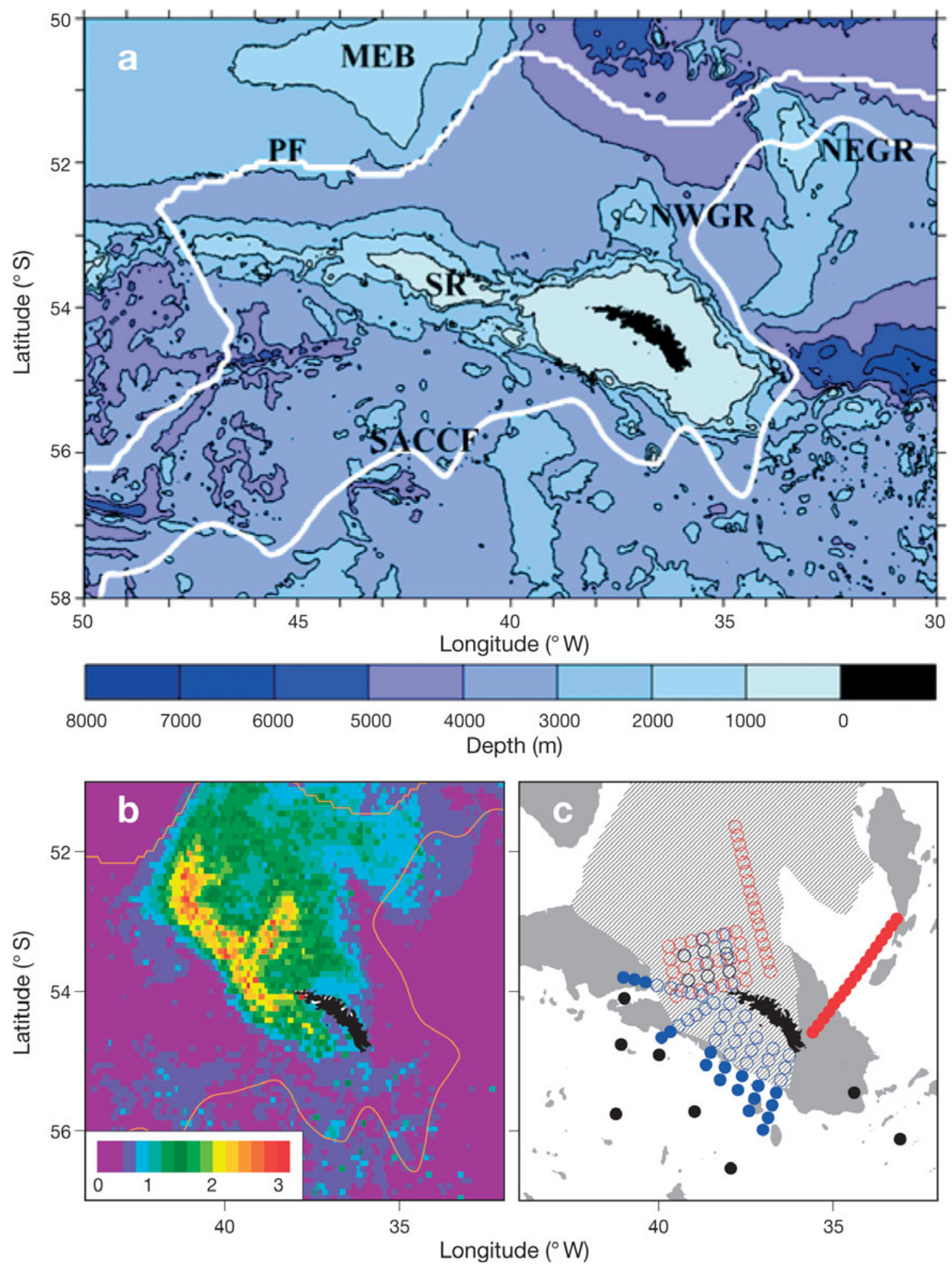

Fig. 1. (a) Main bathymetric features around South Georgia and the average position of the Polar Front (PF) and the Southern Antarctic Circumpolar Current Front (SACCF), represented by white lines. MEB: Maurice Ewing Bank; NEGR: North East Georgia Rise; NWGR: North West Georgia Rise; SR: Shag Rocks. (b) Chl a concentration (mg m ${ }^{-3}$ ): 10 yr composite of SeaWiFS data for the austral summer (mid-December to mid-March 1997 to 2007) of the South Georgia bloom. The average positions of the PF and SACCF are shown as red lines. (c) Station positions; red circles represent the 2002 cruise, black the 2003 cruise and blue the 2005 cruise. Hatched: South Georgia bloom (where chl $a \geq 0.75 \mathrm{mg} \mathrm{m}^{-3}$ ), marking the boundaries between inner bloom stations (O) and stations outside of the main bloom area $(\bullet)$; grey: depth $<2500 \mathrm{~m}$ 
and used to determine relative distributions of phytoplankton biomass.

The depth of the euphotic zone $\left(Z_{e}\right)$ was defined as that of the $1 \%$ incident light level and was calculated by estimating the scalar attenuation coefficient $\left(K_{d}\right)$ of the water column from the linear regression of the log transformed irradiance (PAR) vs. depth profile of the CTDs (Kirk 1994). In the absence of light profiles at nighttime stations, euphotic depth was estimated from relationships between $K_{d}$ and water column-integrated chl a concentrations and was calculated separately for each cruise.

To determine Upper Mixed Layer (UML) depth, the depth and gradient of the maximum density change within a $10 \mathrm{~m}$ window $\left(\Delta \mathrm{kg} \mathrm{m}^{-3}\right)$ were determined, with the midway point within this taken to indicate the UML depth.

Near-surface drifter tracks. As part of the World Ocean Circulation Experiment Surface Velocity Program and the Global Drifter Program (www.aoml.noaa. gov/phod/dac/gdp.html), satellite-tracked drifters have been released near the Antarctic Peninsula and in the Scotia Sea. Drogued at $15 \mathrm{~m}$, these drifters map the near-surface circulation of this region. We selected 25 drifters released between 1995 and 2004 (24 released near the Antarctic Peninsula and 1 released immediately upstream of South Georgia) and used the quality-controlled, $6 \mathrm{~h}$ interpolated data (Hansen \& Poulain 1996) to investigate flow pathways around South Georgia.

Chl a. A description of the method can be found in Korb \& Whitehouse (2004). Briefly, water samples collected with the CTD were filtered through glass fibre filters followed by extraction for $24 \mathrm{~h}$ in $10 \mathrm{ml}$ of $90 \%$ acetone (Parsons et al. 1984). Fluorescence of the extract was measured on a TD-700 Turner fluorometer. Size-fractionated chl a was measured on water samples collected at $20 \mathrm{~m}$ and filtered onto stacked polycarbonate membrane filters with a pore size of 12,2 and $0.2 \mu \mathrm{m}$ for the 2002 and 2003 cruises and onto filters with a pore size of 20, 2 and $0.2 \mu \mathrm{m}$ for the 2005 cruise. For the purposes of the present study pico-, nano- and micro-phytoplankton were represented by the 0.2 to 2,2 to 12 and $>12 \mu \mathrm{m}$ size-fractions for the 2002 and 2003 cruises and by the 0.2 to 2,2 to 20 and $>20 \mu \mathrm{m}$ size-fractions for the 2005 cruise (Sieburth et al. 1978).

SeaWiFS-derived estimates of surface chl a (Level 3, seasonal and cumulative climatologies) were obtained from NASA's Ocean Color Web Site using data reprocessing version 5 (oceancolor.gsfc.nasa.gov/).

Primary production. Primary production was estimated using a method based on the Joint Global Ocean Flux Study (JGOFS) ${ }^{14}$ C-protocol (JGOFS 1996) in conjunction with a simulated in situ incubator. A description of the method can be found in Korb \& Whitehouse (2004). For the 3 cruises, an incubator was sited on the aft deck of the ship; it consisted of 7 clear polycarbonate tubes wrapped in neutral density screening to provide between 0 and $100 \%$ of incident irradiance. Subsamples $(250 \mathrm{ml})$ of water from the CTD were collected into polycarbonate bottles and spiked with $0.1 \mathrm{ml}$ of $\mathrm{NaH}^{14} \mathrm{CO}_{3}$ (activity $0.1 \mathrm{mCi} \mathrm{ml}^{-1}$ ). Bottles were placed in the incubator tubes and left for $24 \mathrm{~h}$. The incubator was cooled with running seawater. At the end of incubations, samples were filtered onto $\mathrm{GF} / \mathrm{F}$ filters, acidified to remove unfixed ${ }^{14} \mathrm{C}$ and counted on a liquid scintillation counter.

Cell counts. The broad taxonomic composition of the micro-phytoplankton was determined from water samples taken at $20 \mathrm{~m}$ depths. Enumeration of the $1 \%$ Lugol-fixed samples was with the Utermöhl (1958) technique on $50 \mathrm{ml}$ aliquots. Only the dominant larger cells were counted, taxonomic resolution being coarse and based on ease and consistency of identification. The cells were counted under an inverted microscope from 2 or 3 perpendicular transects across the whole diameter of the chamber receptacle at $100 \times$ magnification.

Macronutrients. Water samples collected with the CTD were filtered through a mixed ester membrane (pore size $0.45 \mu \mathrm{m}$, Whatman), and the filtrate was analysed colorimetrically for dissolved silicic acid $\left(\mathrm{Si}[\mathrm{OH}]_{4}-\mathrm{Si}\right)$, nitrate $\left(\mathrm{NO}_{3}-\mathrm{N}\right)$, ammonium $\left(\mathrm{NH}_{4}-\mathrm{N}\right)$ and phosphate $\left(\mathrm{PO}_{4}-\mathrm{P}\right)$ with a segmented-flow analyser (Technicon; Whitehouse 1997). The nitrate measurement included nitrite $\left(\mathrm{NO}_{2}\right)$, which is not considered separately as its concentration varied little and typically comprised $<1 \%$ of total $\mathrm{NO}_{3}+\mathrm{NO}_{2}$.

Nutrient deficits for each profile were calculated by subtracting the average UML concentration from generic pre-bloom values of $30 \mathrm{mmol} \mathrm{m}^{-3} \mathrm{NO}_{3}$ and $2 \mathrm{mmol} \mathrm{m}{ }^{-3} \mathrm{PO}_{4}$ for all profiles, and 35 and $45 \mathrm{mmol}$ $\mathrm{m}^{-3} \mathrm{Si}(\mathrm{OH})_{4}$ for the equator and poleward side of the SACCF, respectively. These pre-bloom values were estimated for South Georgia from previous cruises (Whitehouse et al. 1996, 2000, 2008).

Fast repetition rate fluorometry. A Chelsea Instruments Fastracka Fast Repetition-Rate Fluorometer (FRRF) was used on the 2005 cruise to measure vertical profiles of the maximum photochemical quantum efficiency $\left(F_{\mathrm{v}} / F_{\mathrm{m}}\right)$ and functional absorption cross-section $\left(\sigma_{\text {PSII }}\right)$. The FRRF was attached to the cage of an optics rig and deployed at a downcast winch speed of 10 to $15 \mathrm{~m} \mathrm{~min}^{-1}$. Variable fluorescence was induced using a flash protocol of 100 saturation flashes per sequence with a flash duration of $1.1 \mu$ s at a $2.8 \mu$ s interval. The PMT (photomultiplier tube) gain was set to autoranging mode. Only data collected from the 'dark chamber' of the FRRF are presented here. However, due to logis- 
tical constraints, FRRF deployments were performed during all times of day. In surface waters, variations in $F_{\mathrm{v}} / F_{\mathrm{m}}$ and $\sigma_{\mathrm{PSII}}$ may be a function of light as well as nutrient status, and high irradiance can suppress these parameters (Falkowski \& Raven, 1994). Therefore, we followed an approach similar to Vaillancourt et al. (2003) and only considered data at depths where the impact of irradiance was minimal. We averaged the $F_{\mathrm{v}} / F_{\mathrm{m}}$ and $\sigma_{\mathrm{PSII}}$ data over the final $10 \mathrm{~m}$ of water overlaying the bottom of the UML depth (where PAR was $<50 \mu \mathrm{mol} \mathrm{m} \mathrm{m}^{-2}-\mathrm{s}^{-1}$ ) and used this depth interval as an approximation of nutrient stress.

Statistics. Significant differences were tested using a 1-way ANOVA, followed by Tukey's multiple comparison test, unless otherwise stated.

\section{RESULTS}

\section{Passage of near-surface drifters around South Georgia}

A total of 25 drifters released near the Antarctic Peninsula and southwest of South Georgia followed the eastward path of the ACC until they approached the southwestern shelf of South Georgia (Fig. 2). In the region of $\mathrm{ca} .55^{\circ} \mathrm{S}, 40^{\circ} \mathrm{W}$, the drifter paths diverged to pass around the island either to the east or to the west; 9 drifters passed through the deepwater passage to the west of the island and into the Georgia Basin and are hereafter termed as the NW drifters (Fig. 2a). The remaining 16 drifters moved in an eastward direction to pass over or along the island's southern shelf and are termed the E drifters (Fig. 2b).

After passing South Georgia's shelf, the NW drifters joined the bathymetrically steered cyclonic circulation of the Georgia Basin, being moved northwestwards along the Shag Rocks shelf and then northwards along the Maurice Ewing Bank. Only 1 of the 9 NW drifters passed directly into the Georgia Basin (Fig. 2a) without moving along Shag Rocks (1 drifter stopped transmitting data north of the island). Out of the 16 E drifters, 13 passed around the eastern end of South Georgia and directly into, or close to, the area occupied by the 10 yr SG-bloom in Fig. 1b (the remaining E drifters were lost to the south or southeast of the island). Furthermore, 7 of the E drifters moved directly into the core of the $10 \mathrm{yr}$ SG-bloom (the region generally west of $37^{\circ} \mathrm{W}$ ) after passing anticyclonically around the seamount of the Northwest Georgia Rise (Fig. 2b). Travel times from the southwest to the northeast of the study area depicted in Fig. 2 varied between 87 to 189 $\mathrm{d}$ for the NW drifters and between 80 to $289 \mathrm{~d}$ for the E drifters. Mean travel times $( \pm$ SD) were $157( \pm 32)$ and $189( \pm 59)$ d, respectively.

\section{Physical characteristics of the upper water column}

Significant differences in euphotic and UML depths (Table 1) were observed between stations located inside or outside the main SG-bloom area $(p<0.001)$.

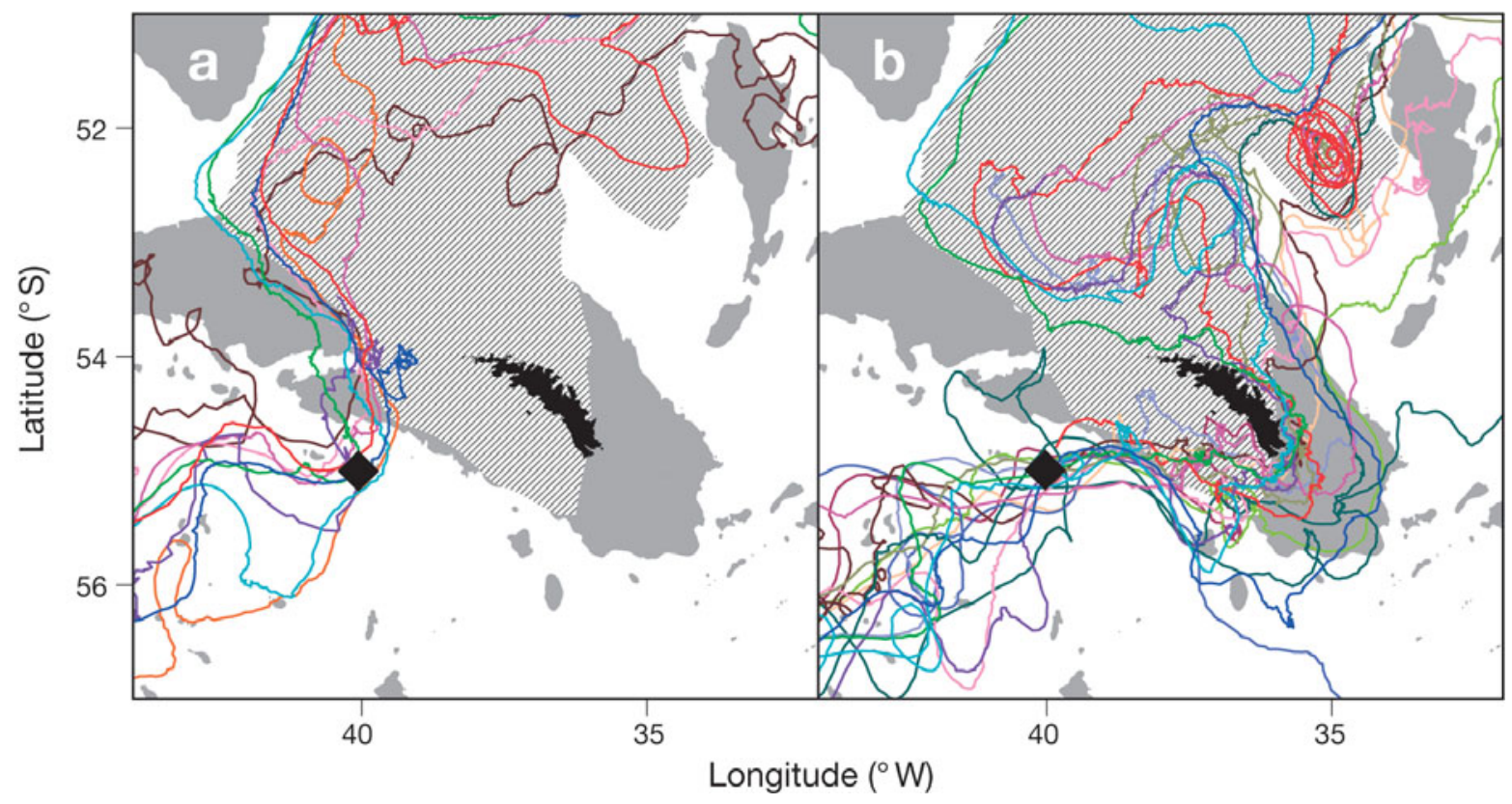

Fig. 2. Tracks of near-surface drifters at South Georgia between 1995 and 2004. ( ), approximate divergence point of drifters at $55^{\circ} \mathrm{S}, 40^{\circ} \mathrm{W}$, after which the drifters pass either (a) to the northwest of the island (9 in total) or (b) to the east (16 drifters in total) 
Table 1. Physical properties of the upper water column during the 2002, 2003 and 2005 cruises. The mean \pm SD and range are shown. Water temperatures (using potential temperature) were averaged over the upper mixed layer (UML)

\begin{tabular}{|cccccc|}
\hline Cruise & $\begin{array}{c}\text { Station } \\
\text { group }\end{array}$ & $\mathrm{N}$ & $\begin{array}{c}\text { UML depth } \\
(\mathrm{m})\end{array}$ & $\begin{array}{c}\text { Euphotic depth } \\
(\mathrm{m})\end{array}$ & $\begin{array}{c}\text { Temperature of UML } \\
\left({ }^{\circ} \mathrm{C}\right)\end{array}$ \\
\hline 2002 & In & 52 & $30 \pm 13(5-64)$ & $29 \pm 8(17-52)$ & $3.97 \pm 0.58(2.83-6.19)$ \\
& Out & 15 & $55 \pm 21(25-90)$ & $57 \pm 12(39-83)$ & $2.97 \pm 0.30(2.46-3.33)$ \\
2003 & In & 6 & $27 \pm 9(15-41)$ & $20 \pm 5(14-25)$ & $4.20 \pm 0.21(3.98-4.47)$ \\
& Out & 8 & $36 \pm 16(15-61)$ & $39 \pm 15(25-60)$ & $3.17 \pm 0.42(2.42-3.74)$ \\
2005 & In & 40 & $38 \pm 8(23-59)$ & $55 \pm 24(10-108)$ & $2.73 \pm 0.48(1.86-3.67)$ \\
& Out & 17 & $47 \pm 9(34-67)$ & $64 \pm 24(32-128)$ & $2.34 \pm 0.50(1.70-3.32)$ \\
\hline
\end{tabular}

core of each bloom occupied the SGbloom region (Fig. 1b). The most concentrated SeaWiFS bloom occurred in 2002, coinciding with the 2002 cruise (Fig. 3a), but was geographically restricted to the region west of $37^{\circ} \mathrm{W}$ in the Georgia Basin. In the summer of 2003 (Fig. 3b; coinciding with the 2003 cruise) the SeaWiFS bloom was less concentrated than in 2002, but spread out to the eastern edge of our study area $\left(32^{\circ} \mathrm{W}\right)$ as well as extending further south than defined by the SG-bloom in

Fig. 1b. The SeaWiFS summer bloom in

Generally, out-stations were characterised by deeper euphotic and UML depths than in-stations. On most cruises, in all regions, UML depths were approximately equal to or shallower than mean euphotic depths, indicating a light environment favourable for phytoplankton growth. However, during the 2003 cruise, UML depth was slightly deeper than euphotic depth at in-stations. Significant differences in temperature (Table 1) were also observed between stations inside and outside of the SG-bloom; generally, upper water column temperatures were higher at in-stations than out-stations, by ca. $1^{\circ} \mathrm{C}$ on the 2002 and 2003 cruise and $0.4^{\circ} \mathrm{C}$ on the 2005 cruise.

\section{Biomass and primary production}

During the time of the 3 cruises, SeaWiFS chl a images revealed phytoplankton blooms associated with South Georgia (Fig. 3). Although the magnitude and extent of these blooms varied from year to year, the
2005 (Fig. 3c; coinciding with the 2005 cruise) was again generally restricted to the Georgia Basin region; a bloom to the south of the island can also be seen but is separated from the northwestern bloom by a band of low chl a water situated along the southern shelf.

Chl a values (integrated over the euphotic depth) measured during the 3 cruises were highest at stations in the SG-bloom region, particularly those situated to the northwest of the island (Fig. $4 \mathrm{a}-\mathrm{c}$ ). The integrated chl a values of out-stations were ca. 2 to 3.4 times lower than at in-stations (Table 2). Overall, mean integrated chl a values for in-stations were significantly higher than those for out-stations ( $p<0.001)$. Mean integrated chl a values remained consistently low at out-stations during all 3 cruises (Table 2). At in-stations, mean chl a values were variable, and twice as high on the 2003 cruise compared to the 2005 cruise (Table 2).

Although fewer measurements of primary production were made compared to chl a biomass, the 2 properties showed similar patterns, whereby the highest production rates were found to the northwest of the
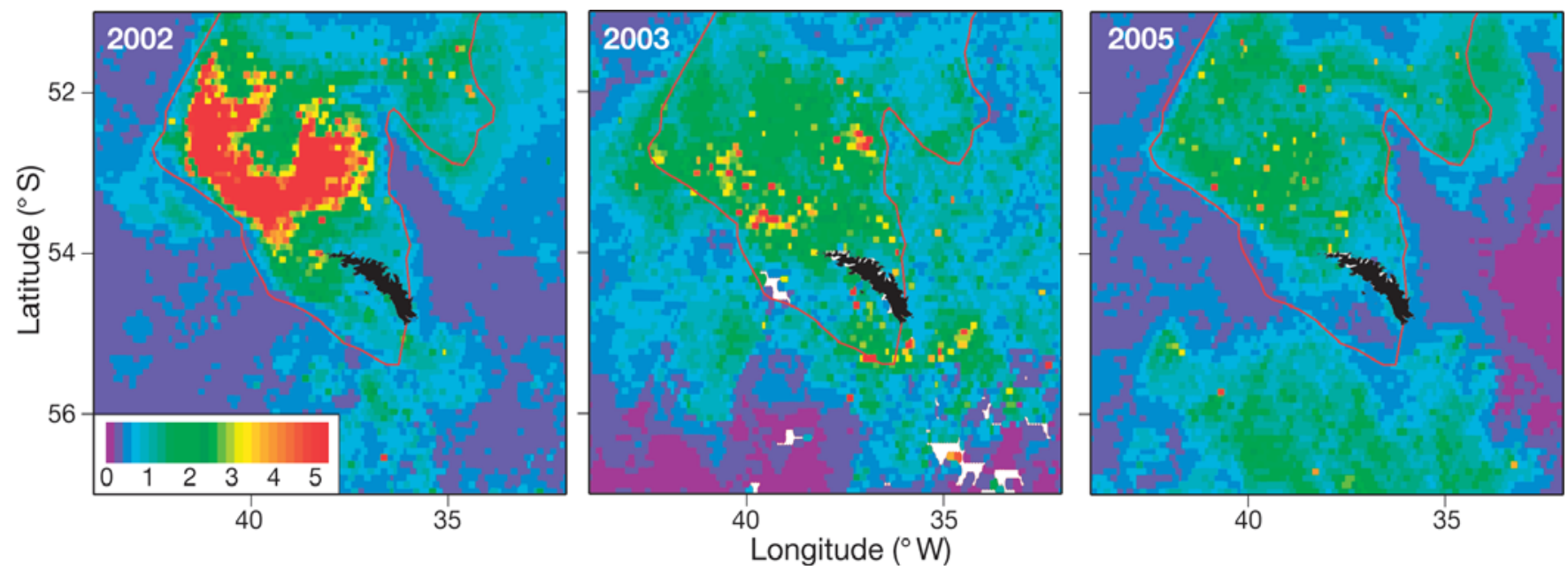

Fig 3. SeaWiFS chl a concentrations $\left(\mathrm{mg} \mathrm{m}^{-3}\right.$ ) from austral summer composites (mid-December to mid-March). The red lines represent the approximate edge of the SG-bloom 


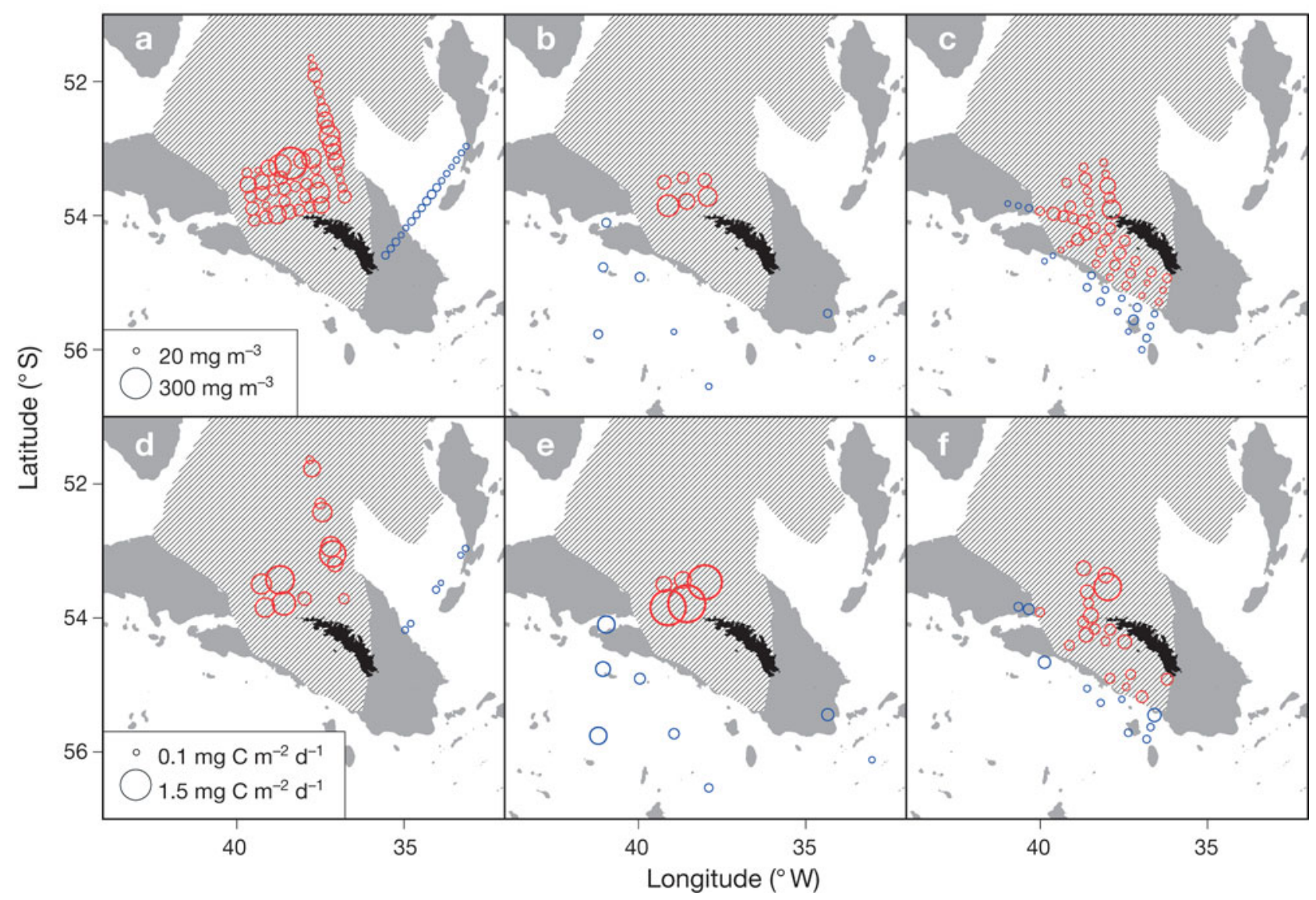

Fig. 4. (a-c) Chl $a$ and $(d-f)$ primary production integrated over the euphotic zone for the 3 cruises (a \& d) 2002, (b \& e) 2003 and (c \& f) 2005. Red circles represent in- and blue circles out-stations

island at stations within the SG-bloom area (Fig. $4 \mathrm{~d}-\mathrm{f}$ ). Overall values were significantly higher, by ca. 2 to 6 times, at in-stations compared to out-stations ( $\mathrm{p}<$ 0.001). However, mean column-integrated primary production rates at both in- and out-stations were variable between cruises. The highest mean production rate of in-stations was seen during the 2003 cruises, which also showed the highest rate for the out-stations (Table 2).

\section{Community composition: size-fractionated $\mathrm{chl} \boldsymbol{a}$ and microplankton cell counts}

Although total chl a concentrations (from samples collected at ca. $20 \mathrm{~m}$; Table 2) were significantly higher at SG-bloom compared with non SG-bloom stations $(p<0.001)$, there were no significant differences in the various size fractions of chl a between the 2 station groups ( $p>0.001)$. Most of the stations around South Georgia were generally dominated by micro-phytoplankton (Fig. 5, Table 2). However, on the 2002 cruise over one-third of all stations sampled showed a high proportion of the smaller size fractions (Fig. 5a). Nanophytoplankton dominated ( $>50 \%$ of the total chl a) over parts of the northern shelf, and pico-phytoplankton was particularly dominant at stations situated over the northwestern part of the shelf. The small size fractions were rarely seen on the 2003 and 2005 cruises, but where they did appear in a mixed community, they were generally restricted to stations south of the island (Fig. 5b \& c).

Cell counts revealed that South Georgia's phytoplankton community, both within and outside of the SG-bloom area, was largely dominated by diatoms on the 3 cruises (Table 2), although dinoflagellates were also found in large numbers during the 2002 cruise. Therefore, significant differences in diatom or dinoflagellate dominance were observed among cruises, but not among station groups ( $p>0.001)$. On the 2003 and 2005 cruises, diatoms accounted for $>60 \%$ of the total cell count at all stations (Table 2). On the 2002 cruise, the distribution pattern of dinoflagellate dominance ( $>60 \%$ of the total cell count) closely followed the pattern of distribution of the smaller chl a size fractions; at in-stations, dinoflagellates were 
Table 2. Biological properties of the upper water column during the 2002, 2003 and 2005 cruises. The mean \pm SD, range (sample size) are shown for parameters integrated over the euphotic depth. Samples for total chl a concentration, size-fractionated chl a and diatom abundance were collected at $20 \mathrm{~m}$

\begin{tabular}{|c|c|c|c|c|c|c|c|c|}
\hline \multirow[t]{2}{*}{ Cruise } & \multirow[t]{2}{*}{$\begin{array}{l}\text { Station } \\
\text { group }\end{array}$} & \multirow[t]{2}{*}{$\begin{array}{l}\text { Integrated chl } a \\
\qquad\left(\mathrm{mg} \mathrm{m}^{-2}\right)\end{array}$} & \multirow{2}{*}{$\begin{array}{l}\text { Integrated } \\
\text { production } \\
\left(\mathrm{g} \mathrm{C} \mathrm{m}^{-2} \mathrm{~d}^{-1}\right)\end{array}$} & \multirow[t]{2}{*}{$\begin{array}{l}\text { Chl } a \text { at } 20 \mathrm{~m} \\
\quad\left(\mathrm{mg} \mathrm{m}^{-3}\right)\end{array}$} & \multicolumn{3}{|c|}{$\begin{array}{c}\text { Size-fractionated chl a } \\
\text { (\% of } 20 \mathrm{~m} \text { total) }\end{array}$} & \multirow{2}{*}{$\begin{array}{c}\text { Diatom abundance } \\
\text { (\% of total } \\
\text { microplankton) }\end{array}$} \\
\hline & & & & & Micro & Nano & Pico & \\
\hline \multirow[t]{4}{*}{2002} & In & $108 \pm 58$ & $0.82 \pm 0.37$ & $3.68 \pm 2.73$ & $50 \pm 34$ & $30 \pm 24$ & $21 \pm 17$ & $67 \pm 33$ \\
\hline & & $\begin{array}{c}18-333 \\
(47)\end{array}$ & $\begin{array}{c}0.22-1.45 \\
\quad(13)\end{array}$ & $\begin{array}{c}0.38-11.82 \\
(46)\end{array}$ & $(46)$ & & & $(48)$ \\
\hline & Out & $32 \pm 12$ & $0.13 \pm 0.04$ & $0.63 \pm 0.33$ & $42 \pm 23$ & $24 \pm 9$ & $34 \pm 17$ & $63 \pm 19$ \\
\hline & & $\begin{array}{c}13-54 \\
(17)\end{array}$ & $\begin{array}{l}0.07-0.17 \\
\quad(6)\end{array}$ & $\begin{array}{l}0.24-1.61 \\
\quad(17)\end{array}$ & (17) & & & $(17)$ \\
\hline \multirow[t]{4}{*}{2003} & In & $\begin{array}{l}138 \pm 46 \\
85-208\end{array}$ & $\begin{array}{c}1.43 \pm 0.65 \\
0.69-2.0\end{array}$ & $\begin{array}{l}5.81 \pm 3.87 \\
1.96-13.28\end{array}$ & & $12 \pm 5$ & $8 \pm 5$ & \\
\hline & & (6) & (5) & (6) & (6) & & & (6) \\
\hline & Out & $41 \pm 20$ & $0.48 \pm 0.24$ & $1.86 \pm 1.31$ & $73 \pm 24$ & $17 \pm 14$ & $10 \pm 9$ & $82 \pm 11$ \\
\hline & & $\begin{array}{c}13-59 \\
(8)\end{array}$ & $\begin{array}{c}0.12-0.79 \\
\quad(8)\end{array}$ & $\begin{array}{c}0.18-3.74 \\
(8)\end{array}$ & (8) & & & (8) \\
\hline \multirow[t]{4}{*}{2005} & In & $67 \pm 33$ & $0.49 \pm 0.25$ & $2.22 \pm 1.63$ & $85 \pm 16$ & $9 \pm 10$ & $6 \pm 6$ & $86 \pm 6$ \\
\hline & & $\begin{array}{c}18-174 \\
(39)\end{array}$ & $\begin{array}{l}0.19-1.38 \\
(19)\end{array}$ & $\begin{array}{c}0.32-6.42 \\
(38)\end{array}$ & (38) & & & $(37)$ \\
\hline & Out & $31 \pm 14$ & $0.28 \pm 0.15$ & $0.70 \pm 0.48$ & $74 \pm 22$ & $16 \pm 15$ & $10 \pm 8$ & $87 \pm 4$ \\
\hline & & $\begin{array}{c}14-68 \\
(18)\end{array}$ & $\begin{array}{l}0.12-0.55 \\
\quad(10)\end{array}$ & $\begin{array}{c}0.06-1.49 \\
\quad(18)\end{array}$ & (18) & & & (18) \\
\hline
\end{tabular}

abundant at 9 stations over the northern shelf and at 2 stations in the Georgia Basin to the far north of the island (data not shown). In addition, dinoflagellates were dominant at 3 out-stations over the shelf and 1 to the far northeast of the island. Phaeocystis spp. were rarely encountered during our 3 cruises, but were observed in very low numbers at only 6 stations out of 134 stations sampled.
At the stations which were dominated by diatoms, 10 species of diatoms were observed in significant numbers (Fig. 6). The contribution of each of these species varied widely among cruises and among stations located within the SG-bloom and those outside. During the 2002 cruise, Thalassiosira spp. were the predominant species at in-stations and Pseudonitzschia spp. at out-stations to the northeast of South Georgia,

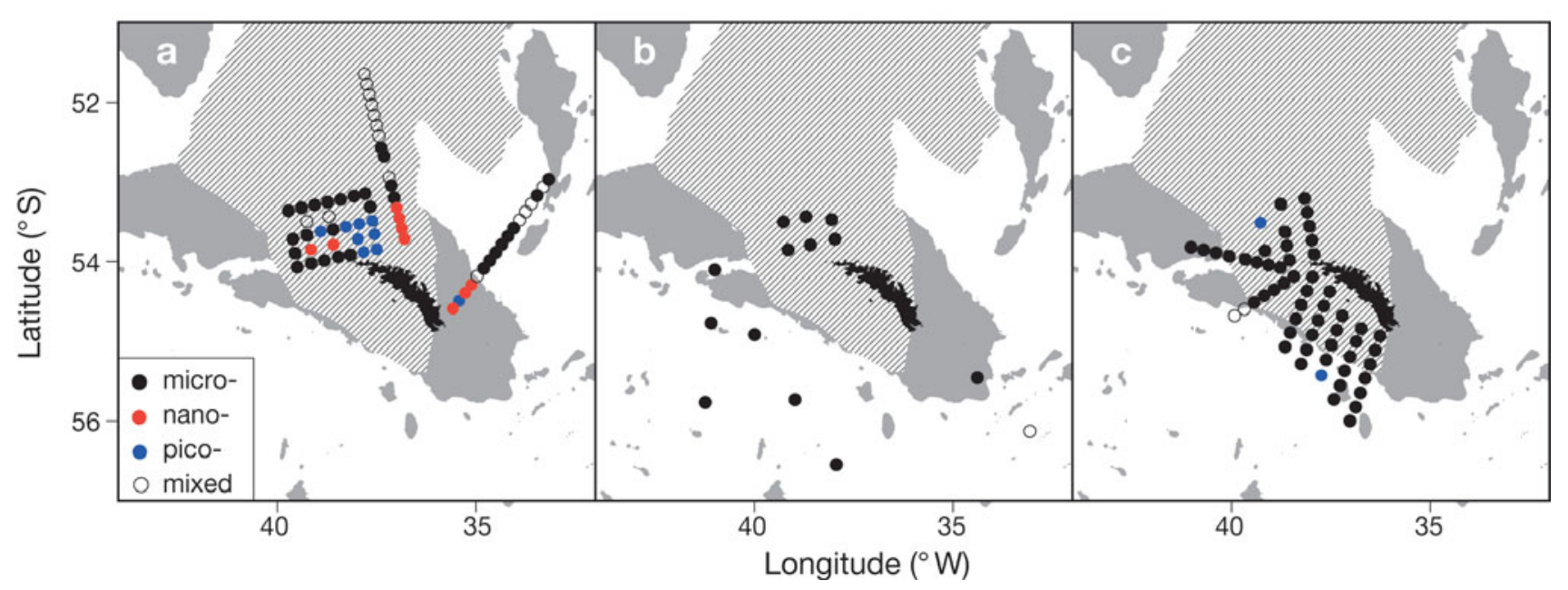

Fig. 5. Size-fractionated chl a for cruises (a) 2002, (b) 2003 and (c) 2005. Coloured circles represent the proportion of the size fraction which accounts for $>50 \%$ of total chl $a$ 


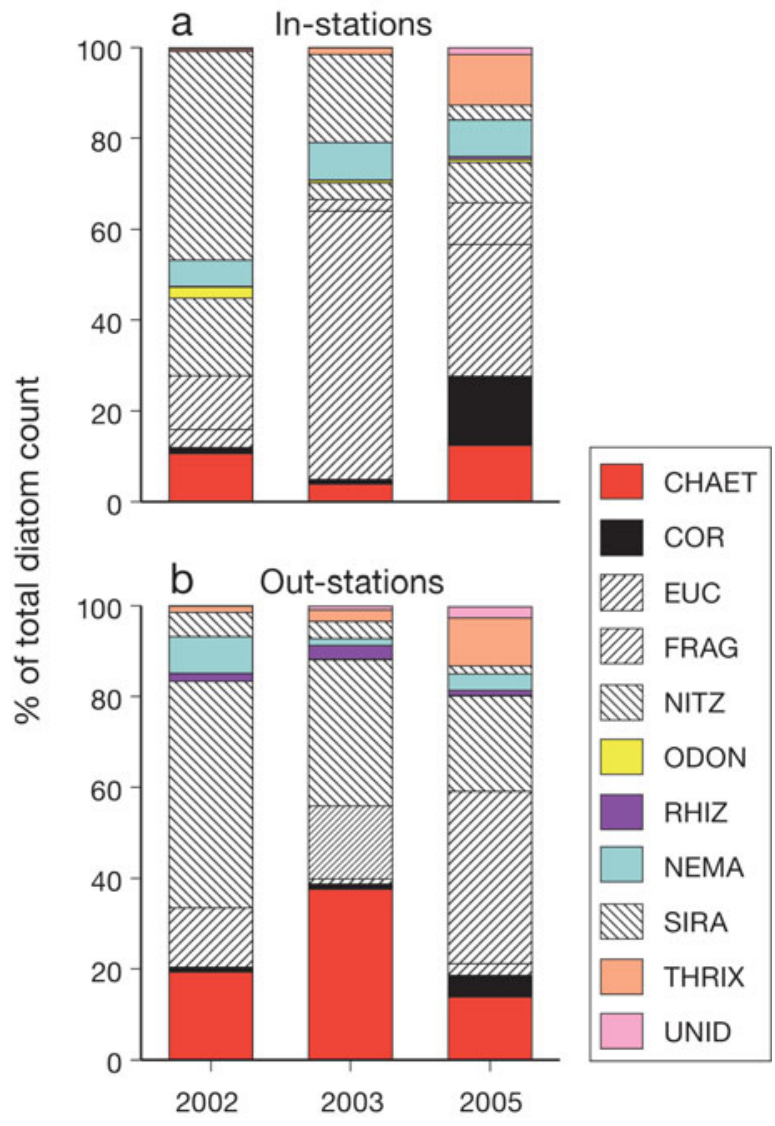

Fig. 6. Main diatom species at stations where diatoms accounted for $>50 \%$ of the total cell count. CHAET, Chaetoceros spp.; COR, Corethron spp.; EUC, Eucampia antarctica; FRAG, Fragilariopsis kerguelensis; NITZ, Nitzschia/Pseudonitzschia spp.; ODON, Odontella spp.; RHIZ, Rhizosolenia/ Proboscia spp.; NEMA, Thalassionema/Fragilariopsis spp.; SIRA, Thalassiosira spp.; THRIX, Thalassiothrix spp.; UNID, unidentified diatoms accounting for 46 and $50 \%$ of the total diatom cell counts, respectively. On the 2003 cruise, the largecelled Eucampia antarctica made up $59 \%$ of the cell counts at in-stations, whilst at out-stations to the south and east, diatoms were mainly comprised of Pseudonitzschia spp. (32\%) and Chaetoceros spp. (38\%). A much more mixed diatom community was observed during the 2005 cruise, although there was a slight dominance again of E. antarctica at in-stations (29\%), and at out-stations Fragilariopsis kerguelensis accounted for $38 \%$ of the total count.

\section{Macronutrient concentrations}

Most macronutrient concentrations were significantly different in the UML of waters within the SGbloom stations compared with those outside (Table 3). For all cruises, $\mathrm{Si}(\mathrm{OH})_{4}, \mathrm{NO}_{3}$ and $\mathrm{PO}_{4}$ levels were significantly lower $(p<0.001)$ at in-stations with the exception of $\mathrm{Si}(\mathrm{OH})_{4}$ during the 2003 cruise for which no significant difference was found. There was more variability with UML $\mathrm{NH}_{4}$ concentrations, which were significantly lower $(\mathrm{p}=0.014)$ at in-stations during the 2002 cruise, but significantly higher at in-stations during both the $2003(\mathrm{p}=0.021)$ and 2005 cruises ( $\mathrm{p}<$ 0.001). Immediately below the UML, $\mathrm{NH}_{4}$ was always highest at in-stations $\left(1.83,2.19\right.$ and $1.61 \mathrm{mmol} \mathrm{m}^{-3}$ for the 2002, 2003 and 2005 cruises, respectively), significantly so $(p=0.001)$ for the 2003 and 2005 cruises.

There were significant differences $(p<0.001)$ in the UML deficit ratios between stations located in or outside of the main SG-bloom during the 2002 and 2005 cruises (Fig. 7, Table 3); $\mathrm{Si}: \mathrm{NO}_{3}$ deficit ratios were significantly lower at in-stations, whereas $\mathrm{NO}_{3}: \mathrm{PO}_{4}$ deficit

Table 3. Macronutrient concentrations $\left(\mathrm{mmol} \mathrm{m}^{-3}\right)$ and deficit ratios averaged over the UML depth. The mean \pm SD and range are shown

\begin{tabular}{|c|c|c|c|c|c|c|c|c|}
\hline Cruise & Station group & $\mathrm{N}$ & $\mathrm{Si}(\mathrm{OH})_{4}$ & $\mathrm{NO}_{3}$ & $\mathrm{PO}_{4}$ & $\mathrm{NH}_{4}$ & $\begin{array}{c}\mathrm{Si}: \mathrm{NO}_{3} \\
\text { deficit ratio }\end{array}$ & $\begin{array}{c}\mathrm{NO}_{3}: \mathrm{PO}_{4} \\
\text { deficit ratio }\end{array}$ \\
\hline \multirow[t]{2}{*}{ Feb 2002} & In & 52 & $\begin{array}{c}12.38 \pm 7.42 \\
1.03-24.86\end{array}$ & $\begin{array}{c}16.23 \pm 3.22 \\
9.78-23.30\end{array}$ & $\begin{array}{c}0.97 \pm 0.32 \\
0.33-1.55\end{array}$ & $\begin{array}{c}0.70 \pm 0.50 \\
0.09-2.03\end{array}$ & $\begin{array}{c}1.65 \pm 0.38 \\
1.05-2.52\end{array}$ & $\begin{array}{c}13.84 \pm 2.35 \\
8.24-26.71\end{array}$ \\
\hline & Out & 17 & $\begin{array}{l}26.68 \pm 5.38 \\
10.85-32.05\end{array}$ & $\begin{array}{l}23.34 \pm 1.95 \\
18.10-25.15\end{array}$ & $\begin{array}{c}1.48 \pm 0.11 \\
1.25-1.69\end{array}$ & $\begin{array}{c}1.05 \pm 0.47 \\
0.46-2.28\end{array}$ & $\begin{array}{c}2.48 \pm 0.45 \\
1.59-3.02\end{array}$ & $\begin{array}{l}13.20 \pm 3.95 \\
8.03-22.89\end{array}$ \\
\hline \multirow[t]{2}{*}{ Feb 2003} & In & 6 & $\begin{array}{c}2.32 \pm 0.53 \\
1.65-3.00\end{array}$ & $\begin{array}{c}12.29 \pm 2.60 \\
9.13-16.00\end{array}$ & $\begin{array}{c}0.48 \pm 0.21 \\
0.27-0.87\end{array}$ & $\begin{array}{c}0.74 \pm 0.44 \\
0.18-1.47\end{array}$ & $\begin{array}{c}1.88 \pm 0.29 \\
1.53-2.32\end{array}$ & $\begin{array}{l}11.71 \pm 1.30 \\
10.26-13.91\end{array}$ \\
\hline & Out & 8 & $\begin{array}{c}18.29 \pm 18.18 \\
1.53-45.29\end{array}$ & $\begin{array}{l}24.88 \pm 3.39 \\
19.59-29.73\end{array}$ & $\begin{array}{c}1.49 \pm 0.24 \\
1.12-1.83\end{array}$ & $\begin{array}{c}0.30 \pm 0.14 \\
0.12-0.57\end{array}$ & $\begin{array}{c}3.97 \pm 1.39 \\
1.95-5.91\end{array}$ & $\begin{array}{c}10.32 \pm 3.08 \\
6.56-14.34\end{array}$ \\
\hline \multirow[t]{2}{*}{ Jan 2005} & In & 40 & $\begin{array}{c}1.06 \pm 0.69 \\
0.21-3.71\end{array}$ & $\begin{array}{l}18.94 \pm 2.65 \\
15.05-23.88\end{array}$ & $\begin{array}{c}1.07 \pm 0.19 \\
0.51-1.40\end{array}$ & $\begin{array}{c}1.05 \pm 0.52 \\
0.11-1.89\end{array}$ & $\begin{array}{c}3.28 \pm 0.85 \\
2.30-5.35\end{array}$ & $\begin{array}{c}11.97 \pm 2.15 \\
8.09-16.75\end{array}$ \\
\hline & Out & 17 & $\begin{array}{l}5.35 \pm 6.23 \\
0.72-23.22\end{array}$ & $\begin{array}{l}23.58 \pm 0.91 \\
22.45-26.05\end{array}$ & $\begin{array}{c}1.34 \pm 0.09 \\
1.19-1.50\end{array}$ & $\begin{array}{c}0.53 \pm 0.22 \\
0.10-0.95\end{array}$ & $\begin{array}{c}4.59 \pm 0.75 \\
2.98-5.61\end{array}$ & $\begin{array}{l}9.87 \pm 1.65 \\
7.75-13.09\end{array}$ \\
\hline
\end{tabular}




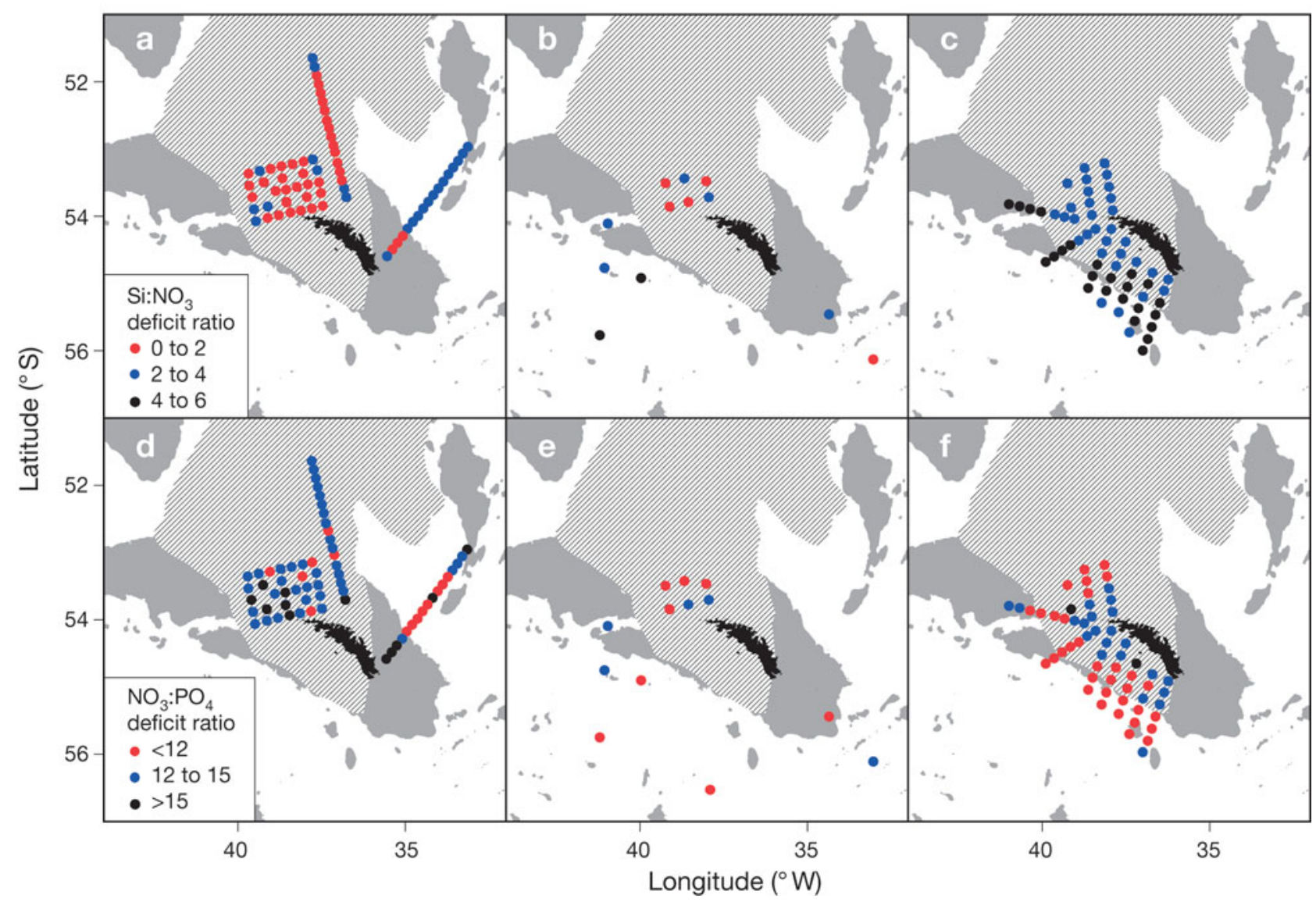

Fig. 7. (a-c) $\mathrm{Si}: \mathrm{NO}_{3}$ and (d-f) $\mathrm{NO}_{3}: \mathrm{PO}_{4}$ deficit ratios integrated over the UML for the 3 cruises, (a \& d) 2002, (b \& e) 2003 and (c \& f) 2005

ratios were significantly higher. Again, for the 2003 cruise, $\mathrm{Si}: \mathrm{NO}_{3}$ deficit ratios were significantly lower ( $p<0.005$ ) within the SG-bloom stations, but no significant difference for $\mathrm{NO}_{3}: \mathrm{PO}_{4}$ deficit ratio was evident. relationship of $\sigma_{\mathrm{PSII}}$ to $F_{\mathrm{v}} / F_{\mathrm{m}}$ was observed, whereby stations outside of the main SG-bloom showed higher $\sigma_{\mathrm{PSII}}$ values than in-stations. In addition, $\sigma_{\mathrm{PSII}}$ was significantly different between the 2 station groups (Student's $t$-test, $\mathrm{p}<0.001)$. At out-stations values ranged

\section{Photochemical efficiency}

The FRRF was only deployed on the 2005 cruise. During this cruise, we found significant differences in $F_{\mathrm{v}} / F_{\mathrm{m}}$ and $\sigma_{\text {PSII }}$ (averaged over the final $10 \mathrm{~m}$ of water overlaying the bottom of the UML depth) between stations located within or outside of the SG-bloom region (Student's t-test, $\mathrm{p}<0.001$ ). $F_{\mathrm{v}} / F_{\mathrm{m}}$ values were higher at in-stations compared to out-stations (Fig. 8) with mean values of $0.42 \pm 0.09(\mathrm{n}=36)$ and $0.29 \pm 0.06(\mathrm{n}=18)$, respectively. At instations, $F_{\mathrm{v}} / F_{\mathrm{m}}$ values ranged from 0.25 up to 0.54 , and at out-stations values ranged from 0.21 to 0.41 . An inverse

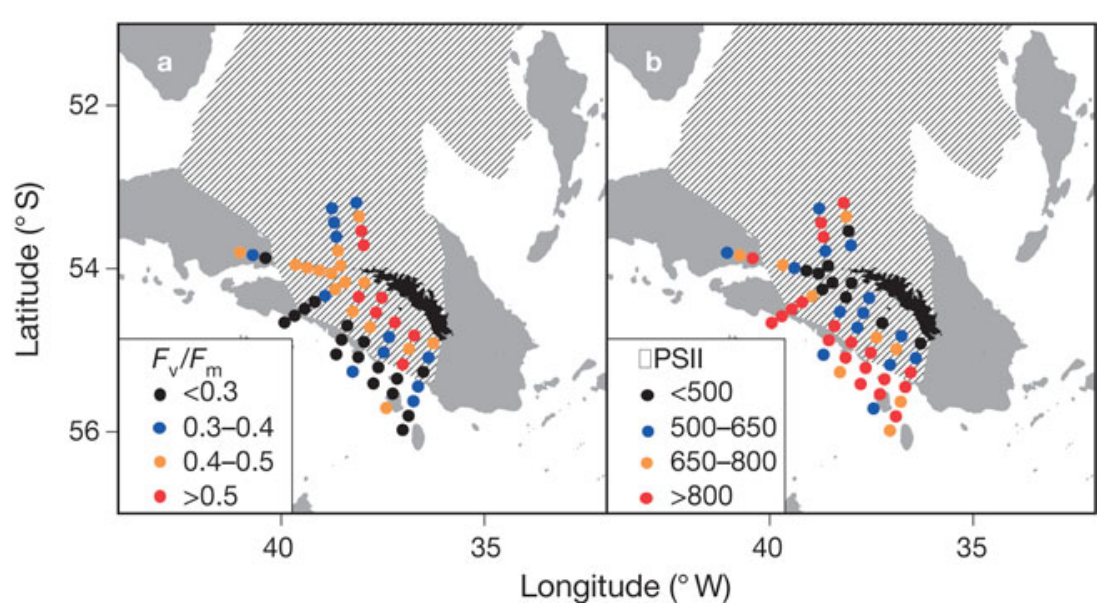

Fig. 8. $F_{\mathrm{v}} / F_{\mathrm{m}}$ and $\sigma_{\mathrm{PSII}}$ values (averaged over the final $10 \mathrm{~m}$ of water overlaying the bottom of the UML) for the 2005 cruise 
from 555 to 943 , with a mean of $789 \pm 127$. At in-stations, values ranged from 354 to 896, with a mean of $617 \pm 168$.

\section{DISCUSSION}

\section{Magnitude and maintenance of the bloom}

South Georgia's annual blooms are some of the most intense and long lasting in the open Southern Ocean. In summer, in situ chl a values $>10 \mathrm{mg} \mathrm{m}^{-3}$ are regularly recorded, whilst ocean colour satellites show the bloom can cover an area of some $53000 \mathrm{~km}^{2}$ and extend for thousands of kilometres downstream of the island (Korb et al. 2004). However, the mechanisms responsible for promoting these blooms are less clear. Alongside these highly productive waters are areas, also close to the island, which are far less productive (Fig. 3). For example, during the present study, both mean water column standing stocks of chl a and primary production rates were 3 times higher at stations situated within the main SG-bloom region compared to those outside (Fig. 4). South Georgia's high productivity is doubtless due to the complex circulation around the island. Here, we examine the mechanisms by which the water flowing around South Georgia may or may not become enriched in both macronutrients and Fe.

The link between South Georgia's blooms and the bathymetry of the North Scotia Ridge is clear. At its southernmost extent, the SG-bloom, defined in the SeaWiFS 10 yr summer composite (Fig. 1b), is restricted to the southwestern shelf of South Georgia and constricted to the north by the Polar Front. The western edge of the bloom is constrained by the bathymetry of the Shag Rocks and the Maurice Ewing Bank. An association between high chl $a$ and bathymetry throughout the open Southern Ocean has been attributed to the topographic features promoting upwelling of Fe and macronutrients into the euphotic zone, where they can then be utilised by local phytoplankton (Comiso et al. 1993, Moore \& Abbott 2000, Holm-Hansen et al. 2005, Tyrrell et al. 2005, Sokolov \& Rintoul 2007). The deep waters may be enriched in nutrients through physical processes such as lateral advection, isopycnal mixing and diapycnal mixing. The Scotia Sea is a site of intense turbulent mixing due to its rough bathymetry (Naveira Garabato et al. 2004). This vigorous mixing is likely to add Fe and macronutrients to the deep waters from the underlying sediments both upstream of and at South Georgia. To the southwest of South Georgia (at $\sim 55^{\circ} \mathrm{S}, 40^{\circ} \mathrm{W}$ ), the divergence of drifter trajectories approaching the island indicates a likely site of upwelling of nutrient-rich deep water. In agreement with this, Whitehouse et al. (2008) found evidence for upwelling of macronutrients on the upstream shelf edge of the island during the 2005 cruise. After the divergence zone, more than one-third of the drifters passed into the deeper waters of the Georgia Basin to the north of the island and into the core of the SGbloom (Fig. 2a).

Almost two-thirds of the drifters took an alternative path to join the main SG-bloom as they moved eastwards from the divergence zone and followed a convoluted route along the southern and eastern shelf (Fig. 2b) of the island. These eastward flowing waters could become enriched in macronutrients and Fe from sediments through deep turbulent mixing over the shelf. Blooms associated with the islands of Kerguelen and Crozet are fertilized by Fe supplied by the islands' plateaus (Blain et al. 2007, Planquette et al. 2007). At Kerguelen, a high supply of Fe to surface waters is attained from enhanced vertical mixing over the shelf, compared to the open ocean, and is probably due to internal wave activity (Blain et al. 2007). In the present study, many drifters passed extremely close to the island itself, where they could also be enriched in nutrients from island runoff. The presence of glacial flour in waters close to the island can be seen in summer true colour satellite images of South Georgia. Furthermore, a number of the eastward drifters passed into the core of the SG-bloom by moving anticyclonically around the northwest Georgia Rise before joining the cyclonic circulation of the Georgia Basin. Such deep features could promote upwelling of nutrient-rich deep water (Moore \& Abbott 2000).

Moore \& Abbott (2002) suggested that bathymetric features in the Southern Ocean, such as the North Scotia Ridge, might destabilize deep-reaching currents and cause enhanced meandering and eddy shedding of the PF, which in turn could inject nutrient-rich waters into the euphotic zone. In Fig. $2 b$, the repeated circling of one of the drifters at $\sim 52^{\circ} \mathrm{S}, 35^{\circ} \mathrm{W}$, near to the average position of the $\mathrm{PF}$, may indicate eddy shedding from the PF. This eddy retained the drifter for almost 3 mo (Thorpe et al. 2002). The SACCF sheds eddies north of South Georgia (Thorpe et al. 2002, Meredith et al. 2003b), and Ward et al. (2002) noted elevated chl $a$ associated with the SACCF to the northeast of South Georgia.

Thus it is likely that the vast phytoplankton blooms that form around South Georgia are supported by several physical processes that act to provide a macronutrient and Fe-rich environment: upwelling of the ACC upstream of the island at the divergence point indicated by the drifter trajectories, upwelling associated with both the PF and the SACCF, eddy-shedding from the fronts acting to transfer nutrients across the fronts, shelf-sediment interactions and island runoff. In addition, drifters took from $\sim 3$ to 9 mo to cross the 
study region depicted in Fig. 2, indicating a long residence time and a continual supply of nutrients to the bloom. As previously noted, South Georgia's bloom can last for many months, from November through March (Korb et al. 2004).

\section{Characteristics and community composition}

In the Southern Ocean, addition experiments have demonstrated that $\mathrm{Fe}$ is an important factor controlling primary productivity (see reviews of de Baar et al. 2005, Boyd et al. 2007). South Georgia's bloom sits in contrast to the HNLC conditions of much of the surrounding ACC and, as discussed previously, receives inputs of macro- and micronutrient-rich water as the ACC interacts with the bathymetry of the North Scotia Ridge. In the present study, ship-based measurements collected during 3 austral summers support the view that South Georgia's phytoplankton communities are characteristic of an Fe-replete environment. A common finding of both artificially induced (summarised in de Baar et al. 2005) and naturally occurring blooms (Blain et al. 2001, Seeyave et al. 2007) is that they are dominated by the larger size-classes of phytoplankton. South Georgia's blooms were also dominated by large phytoplankton; in regards to size-fractionated chl $a_{\text {; }}$ micro-phytoplankton accounted for more than $79 \%$ of the total chl $a$ at almost all stations located inside the SG-bloom region during the 2003 and 2005 cruises and $50 \%$ during the 2002 cruise (Fig. 5, Table 2). Furthermore, this large size-fraction was comprised of diatoms accounting for $67 \%$ of the total phytoplankton cell count on the 2002 cruise and over $85 \%$ of cell counts on the 2003 and 2005 cruises (Table 2).

In the Fe fertilization experiments, Pseudonitzchia spp. or Fragilariopsis kerguelensis were the most successful diatoms following Fe addition (Gall et al. 2001, Coale et al. 2004, Hoffmann et al. 2006, Assmy et al. 2007). F. kerguelensis was again dominant in a naturally Fe-rich bloom found in the PF (de Baar et al. 1995, 1997) and downstream of the island of Kerguelen (Blain et al. 2001). South Georgia's summer blooms also contained these species, although they were never the most abundant species. Instead, much larger diatoms were found to dominate; during the 2002 cruise, Thalassiosira spp. accounted for $49 \%$ of the total diatom count, and Eucampia antarctica made up 59 and $29 \%$ during the 2003 and 2005 cruises, respectively (Fig. 6). Timmermans et al. (2004) demonstrated that the large diatom Thalassiosira requires higher ambient dissolved Fe than the smaller diatom F. kerguelensis. Whilst there are few measurements of Fe to date in the Scotia Sea, exceptionally high levels of total dissolvable $\mathrm{Fe}$, up to $13.6 \mathrm{nM}$ have been recorded in surface waters over South Georgia's northwestern shelf (Holeton et al. 2005). In the wake of the 2005 Kerguelen and Crozet blooms, vertical profiles of the water column revealed that dissolved Fe was low in surface waters but increased with depth (Blain et al. 2007, Planquette et al. 2007). Vertical mixing of Fe-rich deep waters above the plateau is thought to sustain the Kerguelen bloom (Blain et al. 2007, Boyd 2007). South Georgia's blooms are of similar magnitude and duration to those at Kerguelen and may also benefit from a continual supply of new Fe into surface waters from surrounding waters and from below. Thus such a high flux of Fe could help to support the large phytoplankton species found in South Georgia's blooms.

Further evidence for an Fe-replete environment in the bloom can be found by examining the nutrient deficit ratios of the UML. Fe is needed by phytoplankton in order to reduce $\mathrm{NO}_{3}$ to $\mathrm{NH}_{4}$ (Falkowski \& Raven 1994). Therefore, under Fe-replete conditions, phytoplankton have a greater ability to use $\mathrm{NO}_{3}$ as a nitrogen source. $\mathrm{NO}_{3}: \mathrm{PO}_{4}$ depletion ratios, assuming Redfield ratios for N:P uptake, are ca. 16:1. In the SGbloom, $\mathrm{NO}_{3}: \mathrm{PO}_{4}$ depletion ratios were significantly higher than at non SG-bloom stations and are in the range expected under Fe-replete conditions. Silicic acid supply is a key determinant of diatom-dominated blooms, and under high Fe conditions phytoplankton will use equal amounts of nitrate and silicic acid (Hutchins \& Bruland 1998). In the Pacific sector of the Southern Ocean, Fe supply results in a 2- to 5 -fold decrease in the $\mathrm{Si}(\mathrm{OH})_{4}: \mathrm{NO}_{3}$ uptake rates of HNLC populations of phytoplankton (Franck et al. 2000). During 2 of our 3 cruises, $\mathrm{Si}(\mathrm{OH})_{4}: \mathrm{NO}_{3}$ depletion ratios of our bloom stations were between 1.0 and 2.0, which is typical for Fe-replete diatoms. During the 2005 cruise, $\mathrm{Si}(\mathrm{OH})_{4}: \mathrm{NO}_{3}$ depletion ratios were higher, between 2.0 to 4.0 , but still significantly lower compared to offshore stations located outside the SG-bloom. Considerable taxonomic variability in $\mathrm{Si}: \mathrm{N}$ ratios has been observed in diatoms under Fe-replete conditions (Brzezinski 1985, Timmermans et al. 2004), and it is possible that the increase in $\mathrm{Si}(\mathrm{OH})_{4}: \mathrm{NO}_{3}$ depletion ratios during the 2005 cruise was due to a greater presence of heavily silicified diatoms. For example, during the 2005 cruise, $55 \%$ of the diatom population of in-stations was comprised of a mixture of heavily silicified diatoms (Corethron spp., Eucampia antarctica and a Thalassiothrix spp.). In comparison, during the 2002 cruise, weakly silicified Thalassiosira spp. made up $46 \%$ of the diatom community.

Another common finding of artificially induced and naturally Fe-rich blooms in the open Southern Ocean is that photosynthetic efficiency, as measured by $F_{\mathrm{v}} / F_{\mathrm{m}}$ is high (Boyd \& Abraham 2001, Gervais et al. 2002, Sosik \& Olson 2002, Moore et al. 2007). During the aus- 
tral autumn following our 2003 cruise, Holeton et al. (2005) reported high $F_{\mathrm{v}} / F_{\mathrm{m}}$ values of 0.51 and low $\sigma_{\mathrm{PSII}}$ of 810 for stations that were located in our SG-bloom region. In the present study, these parameters were only measured on our 2005 cruise. However, we too found elevated $F_{\mathrm{v}} / F_{\mathrm{m}}(0.43)$ and lowered $\sigma_{\mathrm{PSII}}(630)$ in the stations located inside the SG-bloom region. These stations were located over the northwest and southwest shelf and, as discussed above, are likely to receive inputs of Fe by shelf-sediment interactions.

\section{Role of $\mathrm{Si}(\mathrm{OH})_{4}$}

Whilst much recent attention has focused on the role of Fe in allowing bloom formation in the Southern Ocean, another key determinant is $\mathrm{Si}(\mathrm{OH})_{4}$ supply. Concentrations of $\mathrm{Si}(\mathrm{OH})_{4}$ of 8 to $10 \mathrm{mmol} \mathrm{m}^{-3}$ have been reported to slow down rates of Si uptake in Antarctic phytoplankton, and uptake rates are completely limited at concentrations of $2.5 \mathrm{mmol} \mathrm{m}^{-3}$ in most diatoms (Nelson \& Tréguer 1992, Nelson et al. 2001). Low $\mathrm{Si}(\mathrm{OH})_{4}$ concentration will not necessarily limit diatom growth rates (Nelson \& Dortch 1996). However, Brzezinski et al. (2001) and Nelson et al. (2001) reported that the growth of diatoms, in a bloom which had originally formed at the $\mathrm{PF}$, became limited due to $\mathrm{Si}(\mathrm{OH})_{4}$ depletion in the water column. As a result, the bloom moved progressively southwards following the strong meridional silicic acid gradient of the Southern Ocean.

During the cruises examined in the present study, concentrations of $\mathrm{Si}(\mathrm{OH})_{4}$ at in-stations were depleted to 2.32 and $1.06 \mathrm{mmol} \mathrm{m}^{-3}$ during the 2003 and 2005 cruises, a depletion of at least $30 \mathrm{mmol} \mathrm{m}^{-3}$ when compared to pre-bloom values (see 'Macronutrients'). However, an examination of monthly SeaWiFS images (data not shown) revealed that chl a remained elevated in the SG-bloom region from at least November to March during all 3 cruise seasons. How the bloom was sustained for such a long period, when $\mathrm{Si}(\mathrm{OH})_{4}$ concentration was so low, is unclear. One possibility is that there may be a shift in species composition to a nondiatomaceous community. Alternatively, a continual supply of $\mathrm{Si}(\mathrm{OH})_{4}$ may have sustained diatom growth throughout the austral summer. Surface waters of the 2005 Kerguelen and Crozet blooms were also virtually depleted in $\mathrm{Si}(\mathrm{OH})_{4}$ (Blain et al. 2007, Sanders et al. 2007). Although this macronutrient was rapidly removed from the euphotic zone, the Kerguelen bloom was in part perpetuated by a steady re-supply of $\mathrm{Si}(\mathrm{OH})_{4}$ from surrounding waters (including remineralization processes) and from vertical mixing with shelf waters (Blain et al. 2007, Boyd 2007).

Of the $10 \mathrm{yr}$ of SeaWiFS images that are available to date, the largest, densest bloom around South Georgia was that during the 2001/2002 austral summer, which coincided with our 2002 cruise. Interestingly, $\mathrm{Si}(\mathrm{OH})_{4}$ concentration measured during JR70 did not fall to particularly low values, as mean concentration of the SG-bloom stations was $12.38 \mathrm{mmol} \mathrm{m}^{-3}$. This may be reflected in part to the high abundance of dinoflagellates that were observed in the bloom and/or to a westward intrusion of $\mathrm{Si}(\mathrm{OH})_{4}$ rich waters $(\sim 40 \mathrm{mmol}$ $\mathrm{m}^{-3}$ ) of the SACCF. During the 2002 cruise, the SACCF was ca. $2^{\circ}$ west of its average position, encroaching into the bloom (Korb \& Whitehouse 2004). Eddy-shedding at this front has been proposed as a mechanism for delivering $\mathrm{Si}(\mathrm{OH})_{4}$ to the South Georgia bloom (Whitehouse et al. 1996).

\section{Comparison of stations within and outside of the bloom region}

Given the relatively close proximity of some of the inand out-stations, the complex patterns of water circulation around the island (Fig. 2) and the mean location of the SACCF, it is unlikely that these 2 groups of stations represent entirely different water masses. Nonetheless, many of the characteristics of the stations situated outside of the SG-bloom region were significantly different from those located within the SG-bloom. The outstations do not represent true HNLC conditions as they held mean surface chl a values of 0.63 to $1.86 \mathrm{mg} \mathrm{m}^{-3}$. In fact, on the 2003 cruise, chl a concentrations as high as $3.74 \mathrm{mg} \mathrm{m}^{-3}$ were observed at the northernmost outstation. However, overall water column primary production rates $\left(0.13\right.$ to $\left.0.48 \mathrm{~g} \mathrm{C} \mathrm{m}^{-2} \mathrm{~d}^{-1}\right)$ and chl a biomass (31 to $41 \mathrm{mg} \mathrm{m}^{-2}$ ) of out-stations were considerably lower than at stations inside the SG-bloom. What accounted for this reduced productivity?

Key determinants (in terms of bottom-up controls) creating the HNLC waters of the Southern Ocean are $\mathrm{Fe}$, light and silicic acid supply (Boyd 2002). It is now recognised that the interaction of multiple environmental factors is a key control on phytoplankton processes including growth and nutrient uptake (Cullen 1991). For example, $\mathrm{Si}(\mathrm{OH})_{4}$ uptake rates may depend on Fe availability (Hutchins \& Bruland 1998). Conversely, Franck et al. (2000) reported that Fe-enrichment has little effect on Si-uptake rates when $\mathrm{Si}(\mathrm{OH})_{4}$ concentrations are low. In the present study, much of the waters of the out-station groups had no contact with South Georgia's shelf and likely did not entrain Fe from the islands' shelf sediments (Fig. 2). Low biomass and productivity (Table 2), coupled with low $\mathrm{NO}_{3}: \mathrm{PO}_{4}$ and high $\mathrm{Si}(\mathrm{OH})_{4}: \mathrm{NO}_{3}$ depletion ratios (Table 3) suggest that Fe supply could be a limiting factor on total productivity at stations outside of the main SG-bloom. Out-stations on the 2005 cruise were also charac- 
terised by having lower $F_{\mathrm{v}} / F_{\mathrm{m}}(0.29)$ and higher $\sigma_{\mathrm{PSII}}$ (796) than in-stations, providing further evidence of Fe limitation compared to in-stations (Fig. 8). On the 2002 and 2003 cruises, $\mathrm{Si}(\mathrm{OH})_{4}$ concentrations were relatively high at all out-stations and ca. 2 to 8 times higher than at in-stations (Table 3). However, on our 2005 cruise, out-stations held only modest stocks of $\mathrm{Si}(\mathrm{OH})_{4}$ $\left(\sim 5 \mathrm{mmol} \mathrm{m}^{-3}\right)$. Although these concentrations were twice as high as those reported to limit the Si-uptake rates of diatoms (Nelson \& Tréguer 1992), it is possible that the joint effect of moderately low stocks of $\mathrm{Si}(\mathrm{OH})_{4}$ and Fe were an important control on diatom growth on our 2005 cruise. In addition, increased silicification rates at low dissolved Fe concentrations have been reported in polar diatoms (Takeda 1998), and outstations on the 2005 cruise were dominated by the heavily silicified Fragillariopsis kerguelensis (Fig. 6).

Low irradiance exacerbates the effects of Fe limitation on algal growth in deep mixed layers (Sunda \& Huntsman 1997). In the present study, the UML of outstations (36 to $55 \mathrm{~m}$ ) was slightly deeper than the UML at in-stations (27 to $38 \mathrm{~m}$ ). However, it is unlikely that the light environment of out-stations could account for the reduced productivity seen there. Overall, mean euphotic depths of out-stations were deeper than the depth of the UML (Table 1), and critical depths (calculated as in Nelson \& Smith 1991, data not shown) were always greater than the UML, indicating a light environment favourable for phytoplankton growth.

Although there is little direct evidence of a link between in situ seawater temperature and algal biomass (e.g. Holm-Hansen et al. 2004b), in vitro the temperature optima for growth and photosynthesis of Southern Ocean phytoplankton are higher than ambient water temperature (Tilzer et al. 1986, Smith \& Harrison 1991). Indeed, Reay et al. (2001) suggested that low temperatures, together with Fe limitation, were important in maintaining the HNLC conditions of the Southern Ocean. Under conditions of low Fe availability, phytoplankton may not be fully able to utilise nitrate, a situation that could be aggravated by low temperature (Reay et al. 2001). During our 2002 and 2003 cruises, water temperatures of the UML were lower at out-stations with a $1{ }^{\circ} \mathrm{C}$ difference from in-stations (Table 1). Additionally, $\mathrm{NO}_{3}: \mathrm{PO}_{4}$ deficit ratios were slightly lower than at in-stations, indicating a reduced ability to utilise $\mathrm{NO}_{3}$ as a nitrogen source (Korb \& Whitehouse 2004). Thus the interplay of reduced temperature and Fe limitation could account for the lower production observed at out-stations.

Although out-stations in the present study demonstrated the characteristics of Fe-limited waters, these stations were dominated by the largest chl a size-fraction (micro-phytoplankton), and the cell counts contained mainly diatoms, although dinoflagellates were also present in significant proportions on the 2002 cruise. However, the species composition of diatoms differed from that of the in-stations. Very large diatoms such as Eucampia antarctica and Thalassiosira spp. were not present in large numbers. Instead, Chaetoceros spp., Fragilariopsis kerguelensis and Pseudonitzschia spp. dominated the community. Given the presence of these diatoms, Fe stocks of out-stations are unlikely to be as low as those found in HNLC waters. From curves of growth rate versus added dissolved $\mathrm{Fe}$, the half-saturation constants of $F$. kerguelensis were $\sim 3$ times lower than those of a larger Thalassiosira (Timmermans et al. 2004). Flow patterns around the island (Fig. 2) suggest it is unlikely that out-stations would be re-supplied with Fe during the growth season. Thus an overall reduction in Fe availability, compared to in-stations, may have prevented very large diatoms from blooming there but did allow a modest accumulation of smaller diatoms. Furthermore, the diatoms seen at out-stations were characteristic of moderately low Fe environments. Results of Fe fertilization experiments showed that just prior to Feenrichment, and in true HNLC conditions, F. kerguelensis was present in low numbers, thus indicating this diatom's ability to survive under Fe-limited conditions (Gall et al. 2001, Assmy et al. 2007). During our 2005 cruise, F. kerguelensis was numerically more abundant at out- than in-stations (data not shown) and accounted for a high percentage of the total diatom cell count (Table 3).

\section{CONCLUSION}

The intense blooms near the island of South Georgia are closely constrained by the bathymetry of the North Scotia Ridge, and the interactions of the ACC with this topography lead to the enrichment of nutrients in the surface waters downstream of the island. The dominance of diatoms in South Georgia's blooms, especially the very large species found there, together with high productivity, high photosynthetic efficiency and nutrient deficit ratios typical of Fe-replete environments, suggests that these waters are Fe-rich. In contrast, a low Fe supply at stations outside of the main SG-bloom region may account for the reduced productivity and the absence of very large diatoms observed here. However, Armstrong (1999) outlined the idea that the various factors cited as responsible for HNLC conditions should be viewed as part of a whole and not as alternatives. Stations outside of the main SG-bloom could be simultaneously limited by both Fe and silicic acid (our 2005 cruise) and/or Fe and temperature (our 2002 and 2003 cruises). The intense bloom conditions at South Georgia are likely the result of the interactive 
effects of macronutrient and Fe-replete waters, shallow mixed layers and slightly elevated water temperatures.

The fate of bloom biomass is strongly influenced by its species composition (Smetacek et al. 2004). The present study indicated that the diatom-dominated blooms at South Georgia virtually depleted surface stocks of silicic acid. If this macronutrient were not replaced through the growing season a shift in phytoplankton composition could occur, for example, to a non-diatomaceous community. This in turn could lead to important changes in carbon cycling in this region. South Georgia's blooms last for 4 to 6 mo and extend for thousands of kilometers downstream of the island (Korb et al. 2004). The spatial and temporal magnitude of the bloom is similar to that observed at Kerguelen (Blain et al. 2007) and is likely also sustained by a continuous vertical supply of both macronutrients and Fe which are rapidly utilized in the surface waters by the resident diatom community.

Acknowledgements. This work is a component of the British Antarctic Survey's DISCOVERY-2010 programme. We thank M. Gordan for her help as well as the scientists and crew aboard the RV 'RRS James Clark Ross'. We are grateful to the SeaWiFS Project and the Goddard Earth Sciences Data and Information Services Center for the production and distribution of the SeaWiFS data, respectively. The drifter data were made available through the Interpolated Global Lagrangian Drifter Database, Environmental Data Server at the Atlantic Oceanographic and Meteorological Laboratory, National Oceanic and Atmospheric Administration (available at: http: //www.aoml.noaa.gov/envids/gld/ and www.aoml.noaa.gov/ phod/dac/dacdata.html). We thank P. Boyd and 2 anonymous reviewers for improving this manuscript.

\section{LITERATURE CITED}

Armstrong R (1999) An optimization-based model of iron-light-ammonium colimitation of nitrate uptake and phytoplankton growth. Limnol Oceanogr 44:1436-1446

Assmy P, Henjes J, Klaas C, Smetacek V (2007) Mechanisms determining species dominance in a phytoplankton bloom induced by the iron fertilization experiment EisenEx in the Southern Ocean. Deep-Sea Res I 54:340-362

> Atkinson A, Whitehouse MJ, Priddle J, Cripps GC, Ward P, Brandon MA (2001) South Georgia, Antarctica: a productive, cold water, pelagic ecosystem. Mar Ecol Prog Ser 216: 279-308

Blain S, Tréguer P, Belviso S, Bucciarelli E and others (2001) A biogeochemical study of the island mass effect in the context of the iron hypothesis: Kerguelen Islands, Southern Ocean. Deep-Sea Res I 48:163-187

Blain S, Queguiner B, Armand L, Belviso S and others (2007) Effect of natural iron fertilization on carbon sequestration in the Southern Ocean. Nature 446:1070-1074

Boyd PW (2002) Environmental factors controlling phytoplankton processes in the Southern Ocean. J Phycol 38: 844-861

Boyd PW (2007) Biogeochemistry — iron findings. Nature 446: 989-991
Boyd PW, Abraham ER (2001) Iron-mediated changes in phytoplankton photosynthetic competence during SOIREE. Deep-Sea Res II 48:2529-2550

Boyd PW, Jickells T, Law CS, Blain S and others (2007) Mesoscale iron enrichment experiments 1993-2005: synthesis and future directions. Science 315:612-617

Brzezinski MA (1985) The Si-C-N ratio of marine diatoms interspecific variability and the effect of some environmental variables. J Phycol 21:347-357

Brzezinski MA, Nelson DM, Franck VM, Sigmon DE (2001) Silicon dynamics within an intense open-ocean diatom bloom in the Pacific sector of the Southern Ocean. DeepSea Res II 48:3997-4018

Coale KH, Johnson KS, Chavez FP, Buesseler KO and others (2004) Southern ocean iron enrichment experiment: carbon cycling in high- and low-Si waters. Science 304: $408-414$

Comiso JC, McClain CR, Sullivan CW, Ryan JP, Leonard CL (1993) Coastal zone color scanner pigment concentrations in the Southern Ocean and relationships to geophysical surface-features. J Geophys Res 98(C2):2419-2451

Cullen JJ (1991) Hypotheses to explain high-nutrient conditions in the open sea. Limnol Oceanogr 36:1578-1599

de Baar HJW, de Jong JTM, Bakker DCE, Löscher BM, Veth C, Bathmann U, Smetacek V (1995) Importance of iron for phytoplankton spring blooms and $\mathrm{CO}_{2}$ drawdown in the Southern Ocean. Nature 373:412-415

de Baar HJW, van Leeuwe MA, Scharek RA, Goeyens L, Bakker K, Fritsche P (1997) Nutrient anomalies in Fragilariopsis kerguelensis blooms, iron deficiency and the nitrate/phosphate ratio (A.C. Redfield) of the Antarctic Ocean. Deep-Sea Res II 44: 229-260

de Baar HJW, Boyd PW, Coale KH, Landry MR and others (2005) Synthesis of iron fertilization experiments: from the iron age in the age of enlightenment. J Geophys Res 110: C09S16, doi:10.1029/2004JC002601

Falkowski PG, Raven JA (1994) Aquatic photosynthesis. Blackwell, Malden, MA

> Franck VM, Brzezinski MA, Coale KH, Nelson DM (2000) Iron and silicic acid concentrations regulate Si uptake north and south of the Polar Frontal Zone in the Pacific Sector of the Southern Ocean. Deep-Sea Res II 47: 3315-3338

Gall MP, Boyd PW, Hall J, Safi KA, Chang H (2001) Phytoplankton processes. Part 1: community structure during the Southern Ocean Iron RElease Experiment (SOIREE). Deep-Sea Res II 48:2551-2570

Gervais F, Riebesell U, Gorbunov MY (2002) Changes in primary productivity and chlorophyll a in response to iron fertilization in the Southern Polar Frontal Zone. Limnol Oceanogr 47:1324-1335

Hansen DV, Poulain PM (1996) Quality control and interpolations of WOCE-TOGA drifter data. J Atmos Ocean Technol 13:900-909

Hoffmann LJ, Peeken I, Lochte K, Assmy P, Veldhuis M (2006) Different reactions of Southern Ocean phytoplankton size classes to iron fertilization. Limnol Oceanogr 51: $1217-1229$

> Holeton CL, Nedelec F, Sanders R, Brown L and others (2005) Physiological state of phytoplankton communities in the Southwest Atlantic sector of the Southern Ocean, as measured by fast repetition rate fluorometry. Polar Biol 29: $44-52$

Holm-Hansen O, Kahru M, Hewes CD, Kawaguchi S and others (2004a) Temporal and spatial distribution of chlorophyll-a in surface waters of the Scotia Sea as determined by both shipboard measurements and satellite data. Deep- 
Sea Res I 51:1323-1331

Holm-Hansen O, Naganobu M, Kawaguchi S, Kameda T and others (2004b) Factors influencing the distribution, biomass, and productivity of phytoplankton in the Scotia Sea and adjoining waters. Deep-Sea Res II 51:1333-1350

Holm-Hansen O, Kahru M, Hewes CD (2005) Deep chlorophyll a maxima (DCMs) in pelagic Antarctic waters. II. Relation to bathymetric features and dissolved iron concentrations. Mar Ecol Prog Ser 297:71-81

Hutchins DA, Bruland KW (1998) Iron-limited diatom growth and $\mathrm{Si}$ : $\mathrm{N}$ uptake ratios in a coastal upwelling regime. Nature 393:561-564

JGOFS (1996) Protocols for the Joint Global Ocean Flux Study (JGOFS) core measurements. JGOFS Rep No 19, Intergovernmental Oceanographic Commission, Bergen

Kirk JTO (1994) Light and photosynthesis in aquatic ecosytems. Cambridge University Press, Cambridge

Korb RE, Whitehouse M (2004) Contrasting primary production regimes around South Georgia, Southern Ocean: large blooms versus high nutrient, low chlorophyll waters. Deep-Sea Res I 51:721-738

Korb RE, Whitehouse MJ, Ward P (2004) SeaWiFS in the Southern Ocean: spatial and temporal variability in phytoplankton biomass around South Georgia. Deep-Sea Res II 51:99-116

Larsson AM (2004) The role of mixing in an Antarctic ocean ecosystem: observations and model computations of vertical distributions of related parameters. Deep-Sea Res II 51: 2807-2825

> Meredith MP, Watkins JL, Murphy EJ, Cunningham NJ and others (2003a) An anticyclonic circulation above the Northwest Georgia Rise, Southern Ocean. Geophys Res Lett 30:2061 doi:10.1029/2003GL018039

Meredith MP, Watkins JL, Murphy EJ, Ward P and others (2003b) Southern ACC Front to the northeast of South Georgia: pathways, characteristics, and fluxes. J Geophys Res 108(C5):3162 doi:10.1029/2001JC001227

Moore JK, Abbott MR (2000) Phytoplankton chlorophyll distributions and primary production in the Southern Ocean. J Geophys Res 105(C12):28709-28722

> Moore JK, Abbott MR (2002) Surface chlorophyll concentrations in relation to the Antarctic Polar Front: seasonal and spatial patterns from satellite observations. J Mar Syst 37: 69-86

Moore CM, Seeyave S, Hickman AE, Allen JT and others (2007) Iron-light interactions during the CROZet natural iron bloom and EXport experiment (CROZEX) I: phytoplankton growth and photophysiology. Deep-Sea Res II 54:2045-2065

Naveira Garabato AC, Polzin KL, King BA, Heywood KJ, Visbeck M (2004) Widespread intense turbulent mixing in the Southern Ocean. Science 303:210-213

Nelson DM, Dortch Q (1996) Silicic acid depletion and silicon limitation in the plume of the Mississippi River: evidence from kinetic studies in spring and summer. Mar Ecol Prog Ser 136:163-178

Nelson DM, Smith WO (1991) Sverdrup revisited-critical depths, maximum chlorophyll levels, and the control of Southern-Ocean productivity by the irradiance-mixing regime. Limnol Oceanogr 36:1650-1661

Nelson DM, Tréguer P (1992) Role of silicon as a limiting nutrient to Antarctic diatoms - evidence from kinetic-studies in the Ross Sea Ice-Edge Zone. Mar Ecol Prog Ser 80:255-264

> Nelson DM, Brzezinski MA, Sigmon DE, Franck VM (2001) A seasonal progression of Si limitation in the Pacific sector of the Southern Ocean. Deep-Sea Res II 48:3973-3995

Parsons TR, Maita Y, Lalli CM (1984) A manual of chemical and biological methods for seawater analysis. Pergamon Press, Oxford

Planquette H, Statham PJ, Fones GR, Charette MA and others (2007) Dissolved iron in the vicinity of the Crozet Islands, Southern Ocean. Deep-Sea Res II 54:1999-2019

Pollard RT, Sanders R, Lucas MI, Statham PJ (2007) The Crozet Natural Iron Bloom and Export Experiment (CROZEX). Deep-Sea Res II 54: 1905-1914

Reay DS, Priddle JC, Nedwell DB, Whitehouse MJ, EllisEvans JC, Deubert C, Connelly DP (2001) Regulation by low temperature of phytoplankton growth and nutrient uptake in the Southern Ocean. Mar Ecol Prog Ser 219: 51-64

> Sanders R, Morris PJ, Stinchcombe M, Seeyave S, Venables $H$, Lucas M (2007) New production and the f ratio around the Crozet Plateau in austral summer 2004-2005 diagnosed from seasonal changes in inorganic nutrient levels. Deep-Sea Res II 54:2191-2207

Schlitzer R (2002) Carbon export fluxes in the Southern Ocean: results from inverse modeling and comparison with satellite-based estimates. Deep-Sea Res II 49: 1623-1644

> Seeyave S, Lucas MI, Moore CM, Poulton AJ (2007) Phytoplankton productivity and community structure in the vicinity of the Crozet Plateau during austral summer 2004/2005. Deep-Sea Res II 54: 2020-2044

Sieburth JM, Smetacek V, Lenz J (1978) Pelagic ecosystem structure-heterotrophic compartments of plankton and their relationship to plankton size fractions-comment. Limnol Oceanogr 23:1256-1263

Smetacek V, Assmy P, Henjes J (2004) The role of grazing in structuring Southern Ocean pelagic ecosystems and biogeochemical cycles. Antarct Sci 16:541-558

Smith WO Jr, Harrison WG (1991) New production in polar regions: the role of environmental controls. Deep-Sea Res 38:1463-1479

Sokolov S, Rintoul SR (2007) On the relationship between fronts of the Antarctic Circumpolar Current and surface chlorophyll concentrations in the Southern Ocean. J Geophys Res 112, C07030, doi:10.1029/2006JC004072

Sosik HM, Olson RJ (2002) Phytoplankton and iron limitation of photosynthetic efficiency in the Southern Ocean during late summer. Deep-Sea Res I 49: 1195-1216

Sunda WG, Huntsman SA (1997) Interrelated influence of iron, light and cell size on marine phytoplankton growth. Nature 390:389-392

> Takeda S (1998) Influence of iron availability on nutrient consumption ratio of diatoms in oceanic waters. Nature 393: 774-777

Thorpe SE, Heywood KJ, Brandon MA, Stevens DP (2002) Variability of the southern Antarctic Circumpolar Current Front north of South Georgia. J Mar Syst 37:87-105

Tilzer MM, Elbrächter M, Gieskes WW, Beese B (1986) Light-temperature interactions in the control of photosynthesis in Antarctic phytoplankton. Polar Biol 5:105-111

Timmermans KR, van der Wagt B, de Baar HJW (2004) Growth rates, half-saturation constants, and silicate, nitrate, and phosphate depletion in relation to iron availability of four large, open-ocean diatoms from the Southern Ocean. Limnol Oceanogr 49:2141-2151

Tyrrell T, Merico A, Waniek JJ, Wong CS, Metzl N, Whitney F (2005) Effect of seafloor depth on phytoplankton blooms in high-nitrate, low-chlorophyll (HNLC) regions. J Geophys Res B 110(G2):G02007, doi:10.1029/2005JG000041

Utermöhl H (1958) Zur Vervollkommnung der quantitativen Phytoplankton-Methodik. Mitt Int Ver Theor Angew Limnol 9:1-38 
Vaillancourt RD, Sambrotto RN, Green S, Matsuda A (2003) Phytoplankton biomass and photosynthetic competency in the summertime Mertz Glacier Region of East Antarctica. Deep-Sea Res II 50:1415-1440

Ward P, Whitehouse M, Meredith M, Murphy E and others (2002) The southern Antarctic circumpolar current front: physical and biological coupling at South Georgia. DeepSea Res I 49:2183-2202

Whitehouse MJ (1997) Automated seawater nutrient chemistry. British Antarctic Survey, Cambridge

Whitehouse MJ, Priddle J, Symon C (1996) Seasonal and

Editorial responsibility: Graham Savidge,

Portaferry, UK annual change in seawater temperature, salinity, nutrient and chlorophyll a distributions around South Georgia, South Atlantic. Deep-Sea Res I 43: 425-443

- Whitehouse MJ, Priddle J, Brandon MA (2000) Chlorophyll/ nutrient characteristics in the water-masses to the north of South Georgia, Southern Ocean. Polar Biol 23:373-382

Whitehouse MJ, Korb RE, Atkinson A, Thorpe SE, Gordon M (2008) Formation, transport and decay of an intense phytoplankton bloom within the High-Nutrient LowChlorophyll belt of the Southern Ocean. J Mar Syst 70: 150-167

Submitted: December 17, 2007; Accepted: April 15, 2008 Proofs received from author(s): September 12, 2008 